\section{Pacific Northwest}

National Laboratory

Operated by Battelle for the

U.S. Department of Energy

\title{
Summary of Hanford Site Groundwater Monitoring for Fiscal Year 2004
}

\author{
Editors \\ M. J. Hartman
L. F. Morasch
W. D. Webber
}

March 2005

Prepared for the U.S. Department of Energy under Contract DE-AC05-76RL01830 


\title{
DISCLAIMER
}

This report was prepared as an account of work sponsored by an agency of the United States Government. Reference herein to any specific commercial product, process, or service by trade name, trademark, manufacturer, or otherwise does not necessarily constitute or imply its endorsement, recommendation, or favoring by the United States Government or any agency thereof, or Battelle Memorial Institute.

\author{
PACIFIC NORTHWEST NATIONAL LABORATORY \\ operated by \\ BATTELLE \\ for the \\ UNITED STATES DEPARTMENT OF ENERGY \\ under Contract DE-AC05-76RL01830 \\ Printed in the United States of America \\ Available to DOE and DOE contractors from the \\ Office of Scientific and Technical Information, P.O. Box 62, Oak Ridge, TN 37831; \\ prices available from $(615) 576-8401$. \\ Available to the public from the National Technical Information Service, \\ U.S. Department of Commerce, 5285 Port Royal Rd., Springfield, VA 22161
}

By This document was printed on recycled paper. 


\section{Summary of Hanford Site Groundwater Monitoring for Fiscal Year 2004}

\section{Editors}

M. J. Hartman

L. F. Morasch

W. D. Webber

March 2005

Prepared for the U.S. Department of Energy by Pacific Northwest National Laboratory under Contract DE-AC05-76RL01830, with contributions from CH2M HILL Hanford Group, Inc.; Fluor Hanford, Inc.; Lawrence Berkley National Laboratory; S.M. Stoller Corporation; and University of Nevada

Pacific Northwest National Laboratory

Richland, Washington 99352 


\section{Contents}

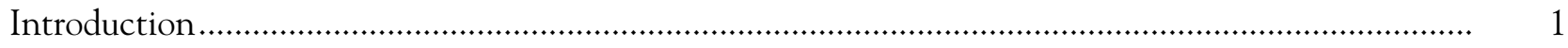

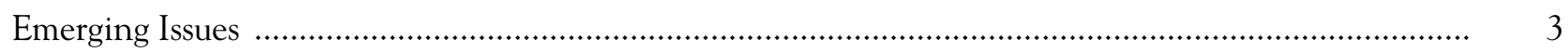

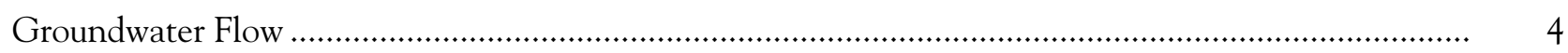

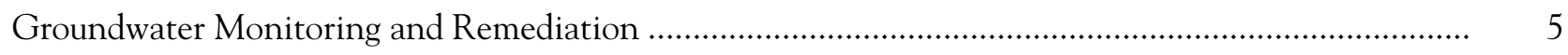

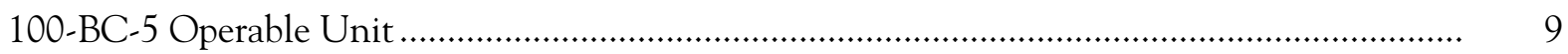

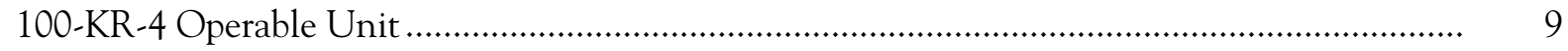

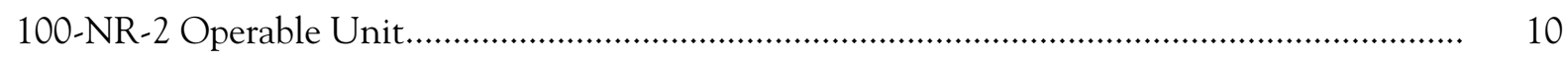

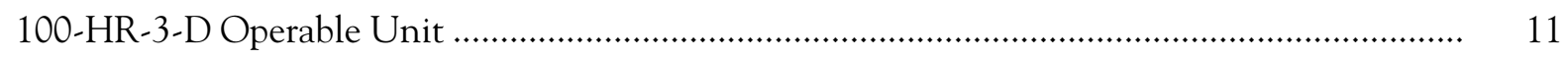

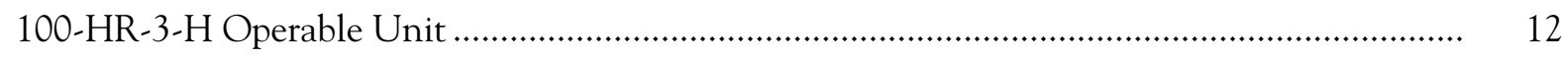

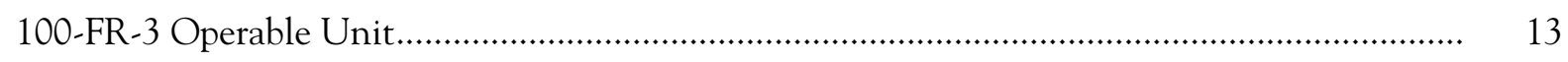

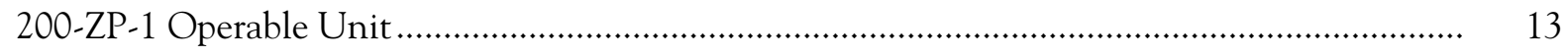

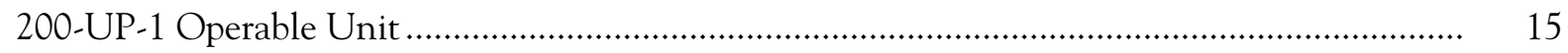

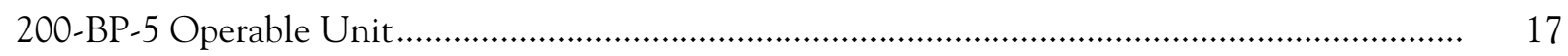

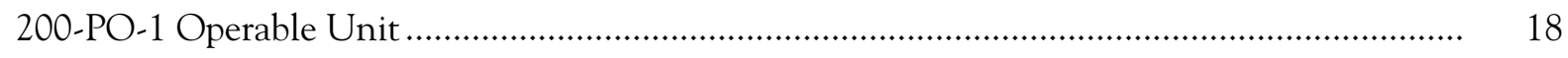

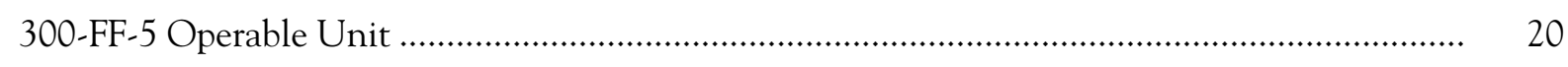

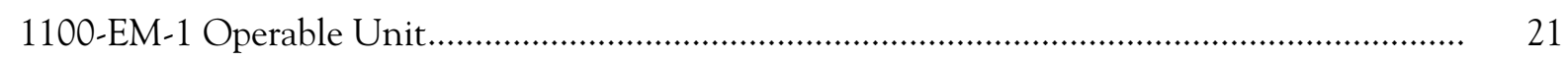

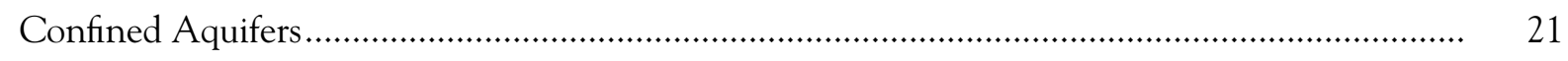

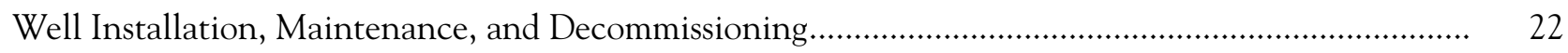

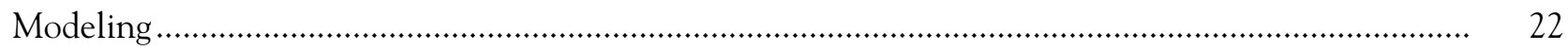

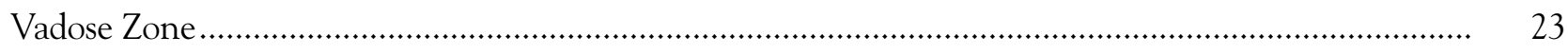

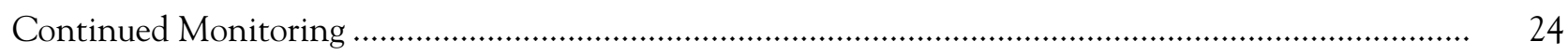


The Hanford Site, a facility in the U.S. Department of Energy (DOE) nuclear weapons complex, encompasses $~ 1,517$ square kilometers northwest of the city of Richland along the Columbia River in southeast Washington State. The federal government acquired the site in 1943, and until the 1980s, it was dedicated primarily to the production of plutonium for national defense and the management of resulting waste. Beginning in the 1990s, DOE has focused on cleaning up the site.

DOE is committed to protecting the Columbia River from contaminated groundwater resulting from past, present, and future operations and protecting and remediating groundwater. The Hanford Site Groundwater Strategy focuses on three key areas: groundwater protection, groundwater monitoring, and remediation of contaminated groundwater.

DOE monitors groundwater at the Hanford Site to fulfill a variety of state and federal regulations, including the Atomic Energy Act of 1954 (AEA), the Resource Conservation and Recovery Act (RCRA), the Comprehensive Environmental Response, Compensation, and Liability

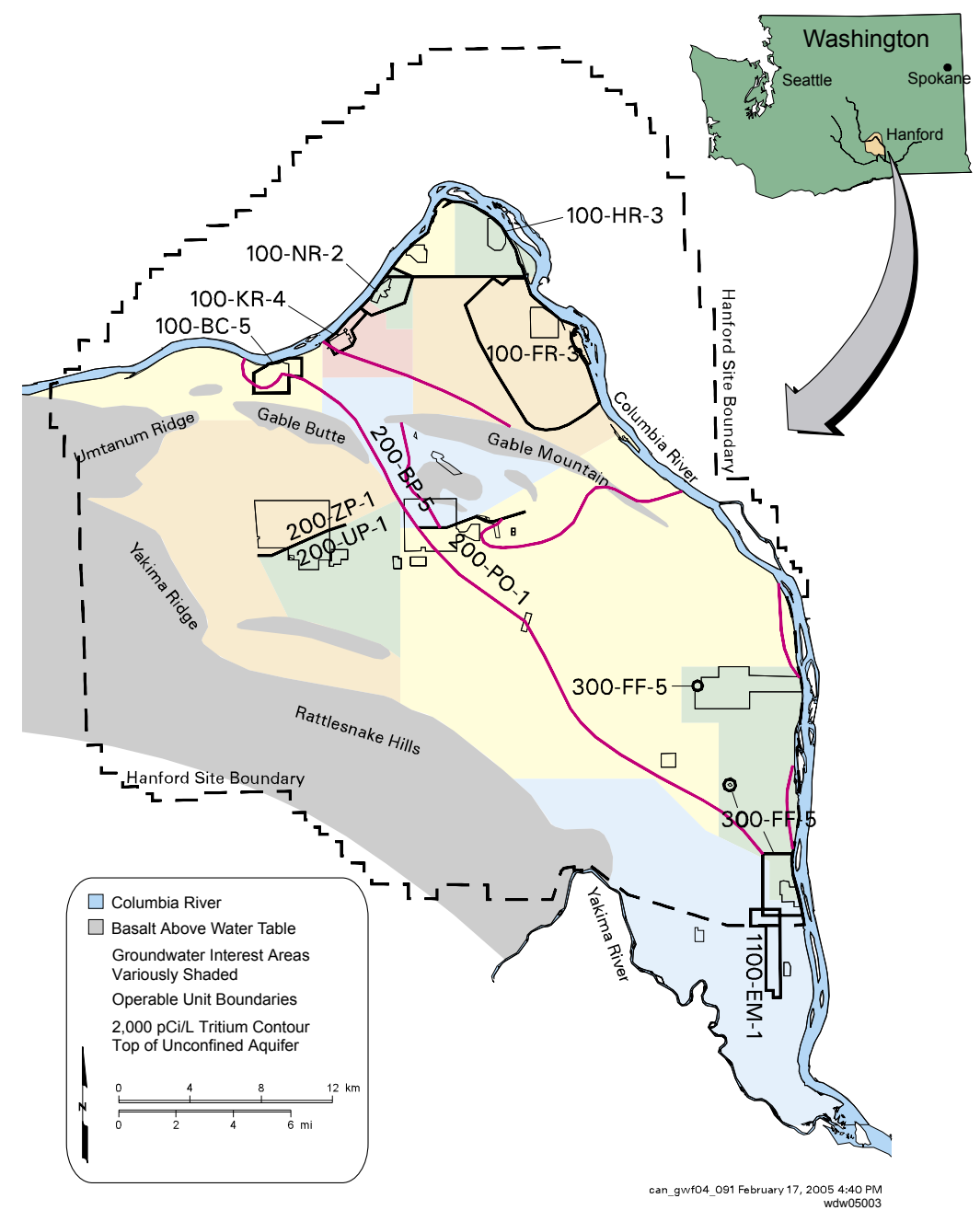

Hanford Site groundwater monitoring is organized by areas of interest, which are informally named after the groundwater operable units. The areas of interest are useful for planning and scheduling groundwater monitoring and interpreting data.
The Hanford Site

Groundwater

Strategy focuses

on three key areas:

groundwater

protection,

groundwater

monitoring, and

remediation of

contaminated

groundwater. 


\section{DOE sampled}

730 wells

during FY 2004.

Iodine-129, nitrate, and tritium are the most widespread contaminants.
Act (CERCLA), and Washington Administrative Code (WAC). DOE manages most of these activities through the Groundwater Performance Assessment Project (groundwater project).

Some contamination reached the Columbia River by moving downward from waste sites through the vadose zone, into the groundwater, and then into the river. The analysis of groundwater samples helps determine the potential effects that contaminants could have on human health and the environment. DOE works with regulatory agencies such as the U.S. Environmental Protection Agency (EPA) and the Washington State Department of Ecology (Ecology) to make cleanup decisions based on sound technical information and the technical capabilities available.

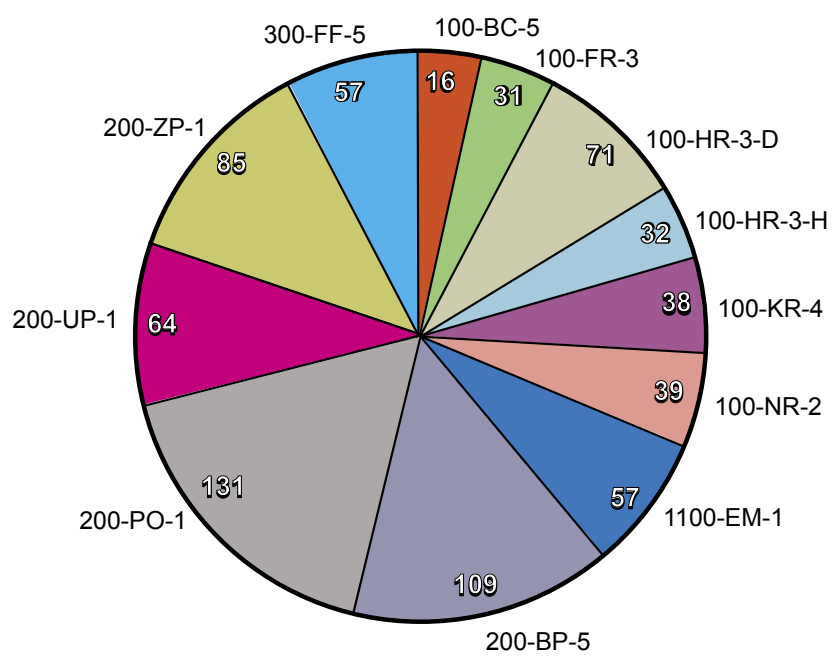

ecs05001

This chart shows the number of wells sampled in each groundwater interest area in FY 2004.

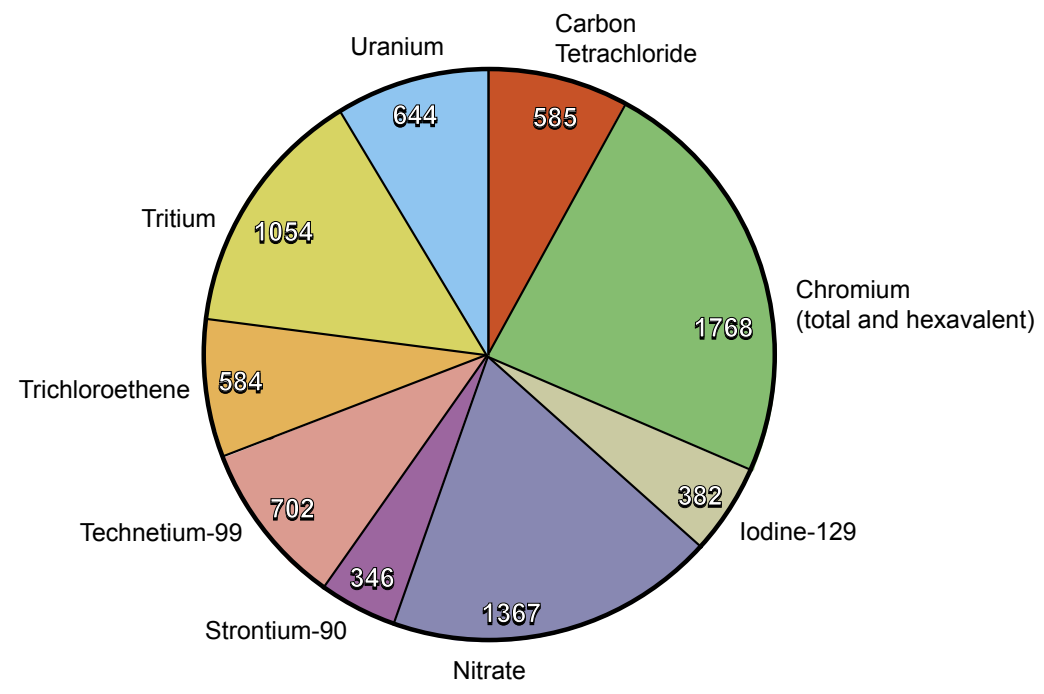

ecs05002

The groundwater project requests specific laboratory analyses based on the well's location, historical contaminant trends, and regulatory requirements. This graph shows the number of analyses for the most common constituents during FY 2004. 
In fiscal year (FY) 2004, workers sampled 730 monitoring wells and 139 shoreline aquifer tubes to determine the distribution and movement of contaminants. Many of the wells were sampled multiple times during the year for a total of 2,026 sampling trips. A total of 1,768 samples of Hanford groundwater were analyzed for chromium, 1,367 for nitrate, and 1,054 for tritium. Other constituents frequently analyzed include technetium-99 (702), carbon tetrachloride (585), and uranium (644).

\section{Emerging Issues}

Tritium at KE Basin. Tritium levels began to rise in January 2003 in a well downgradient of the KE Basin, exceeding 100,000 pCi/L in October 2003 and subsequently declining to $\sim 40,000 \mathrm{pCi} / \mathrm{L}$ in October 2004. Because there are multiple sources of tritium in the area, no mobile co-contaminants such as technetium-99 are found with the tritium, and there is no evidence of measurable water losses from the KE Basin, scientists cannot conclude with certainty that the recent rise in tritium is a result of current loss of shielding water to the ground. Other potential sources of tritium include remobilization of tritium in the soil from a 1993 basin leak and remobilization of tritium in the soil from the remediation of condensate cribs. Cracks have been found in the concrete basins that still contain sludge and shielding water contaminated with tritium and other radionuclides. The extent of the cracking and possible impacts on groundwater are being investigated. The frequency of groundwater sample collection downgradient of the KE Basin has been increased to help evaluate the source of the tritium.

Technetium-99 at Waste Management Area T. Concentrations continued to increase in wells on the east side (downgradient) of the tank farm in FY 2004. Well 299-W11-39, near the northeast corner of the waste management area, had a concentration of $21,400 \mathrm{pCi} / \mathrm{L}$ at the end of FY 2004, more than double the FY 2003 concentration of 9,140 pCi/L. Preliminary data from a new well installed in early FY 2005 east of Waste Management Area T showed a technetium-99 concentration of $182,000 \mathrm{pCi} / \mathrm{L}$ at $\sim 10$ meters below the water table. DOE will work with the regulatory agencies to develop actions in response to the technetium-99 increases.

100-N Pump-and-Treat Alternatives. Because pump-and-treat technology is not an effective way to clean up strontium-90 contamination, DOE is considering alternative technologies. DOE has developed a treatability test plan to evaluate the effectiveness of one technology, sequestration, where chemicals injected into the aquifer immobilize strontium-90 so it does not flow with the groundwater into the Columbia River. The plan includes a contingency provision for a permeable reactive barrier installed with compressed air to meet the same objective if sequestration fails. The test will also evaluate phytoremediation (plants) to enhance strontium-90 recovery along the shoreline. DOE has recommended temporarily suspending operation of the pump-and-treat system while they collect data to evaluate the alternative technologies. Sampling frequency was increased in anticipation of suspending the pump-and-treat operations. DOE also recommends monitored natural attenuation for that portion of the plume that is not expected to reach the Columbia River.

100-D Chromium Remediation. DOE began operating a new small-scale pump-andtreat system in the central 100-D Area, where hexavalent chromium was bypassing two existing remediation systems. If the new system is successful and cost-effective, it may be expanded.

Proposed Pump-and-Treat Cessation at 200-UP-1 Operable Unit. Technetium-99 and uranium concentrations were below interim action goals in FY 2004. DOE and Ecology have agreed to perform a rebound study to verify the effectiveness of the pump-and-treat actions at removing uranium and technetium-99 contamination in the groundwater. The pumpand-treat system will be turned off for 1 year, and DOE will sample and analyze groundwater monthly to determine how uranium and technetium-99 concentrations change when the aquifer is not stressed by continuous pumping.
$D O E$ is investigating recent changes in tritium concentrations downgradient of KE Basin in the 100-K Area and increases in technetium-99 concentrations east of Waste Management Area T. 


\section{Hanford} groundwater flows into the Columbia

River, which is used for recreation, drinking water, agriculture, and wildlife habitat. Therefore, DOE is focusing their remediation efforts

\section{Columbia River.} on protecting the

Well Spacing at the Low-Level Burial Grounds. DOE and Ecology have been holding workshops regarding some aspects of groundwater monitoring at these sites. One of the issues to be resolved is the horizontal spacing and number of groundwater monitoring wells to be installed to meet RCRA groundwater monitoring requirements.

Alternative Statistics at RCRA Sites. DOE completed data collection and evaluation of an alternative statistical method for groundwater monitoring data. This method, using control charts, has been proposed to Ecology for use in RCRA groundwater monitoring. Discussions with Ecology in the next year are hoped to resolve the applicability of this method.

Well Decommissioning. DOE has accelerated the rate at which "at-risk" and unused wells are being decommissioned. This activity will continue to be a high priority for DOE to stop and/or prevent the risk of contaminants moving through these wells.

Feasibility Studies. DOE began a focused feasibility study of the 300-FF-5 Operable Unit, which will lead to final cleanup decisions. Similar studies are scheduled to being in the 100-BC-5 and 100-FR-3 operable units in FY 2005 and 2006.

\section{Groundwater Flow}

Groundwater in the unconfined aquifer generally flows from west to east across the Hanford Site to discharge areas along the Columbia River. The direction of groundwater flow is inferred from water-table elevations, barriers to flow (e.g., basalt or mud units at the water table), and the distribution of contaminants.

General directions of groundwater flow are illustrated on

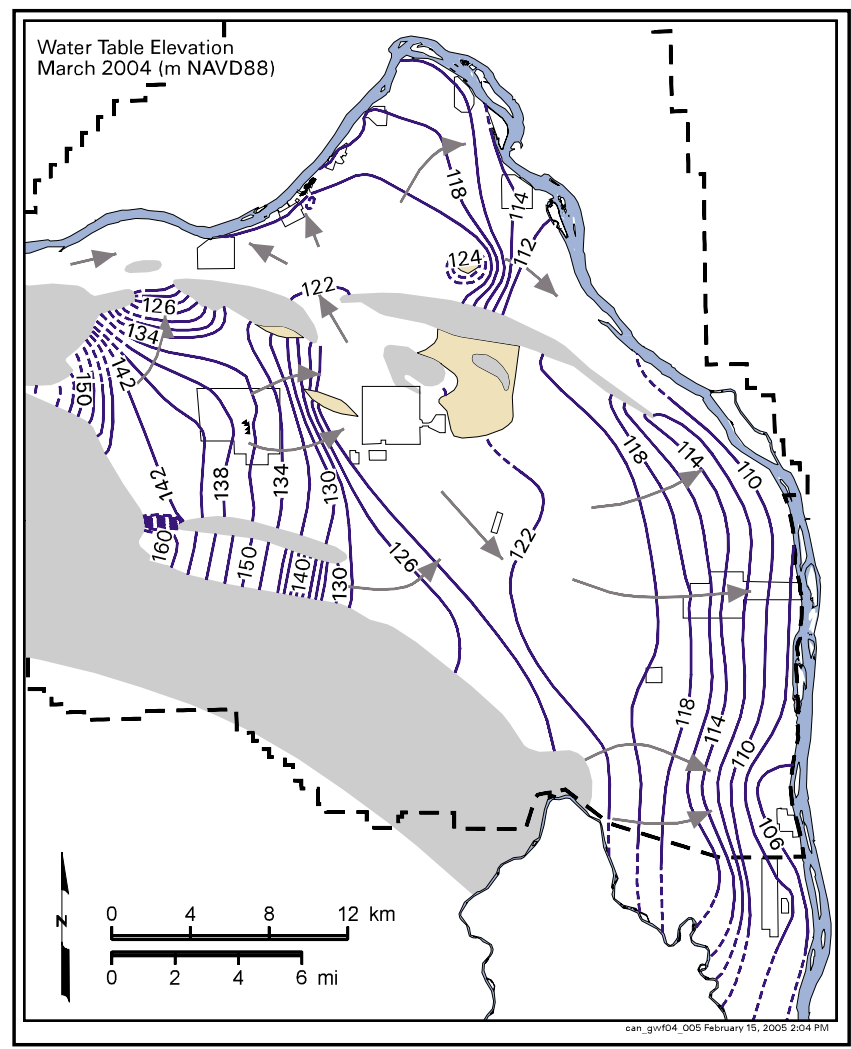

This map shows the water table and inferred flow directions in March 2004. Areas shaded in gray or tan show where the unconfined aquifer is absent. the map for March 2004. Groundwater enters the Hanford Site from recharge areas to the west and eventually discharges to the Columbia River. In the part of the site north of Gable Mountain and Gable Butte, groundwater flows generally northeast or east, except beneath the reactor areas on the west side of the horn where groundwater flows north and northwest toward the river. South of Gable Mountain and Gable Butte, groundwater flows toward the east and southeast. The water table in the central part of the site (beneath the 200 East Area) is relatively flat because of the presence of highly permeable sediment of the Hanford formation at the water table. In the south part of the Hanford Site, groundwater converges on the 300 Area from the northwest, west, and southwest.

The natural pattern of groundwater flow was altered during the Hanford Site's operating years by the formation of mounds in the water table. The mounds were created by the discharge of large volumes of wastewater to the ground and were present in each reactor area and beneath the 200 Areas. Since effluent disposal decreased significantly in the 1990s, these mounds are disappearing.

Groundwater flow is currently altered where extraction or injection wells are used for pump-and-treat systems or where wastewater is discharged to the land surface.

East of the 200 East Area, a fine-grained confining unit creates a barrier to movement in the surrounding unconfined aquifer. Beneath this confining unit, the uppermost aquifer is a permeable unit in the Ringold Formation. Groundwater flow in this confined aquifer still is influenced by a residual recharge mound. 


\section{Groundwater Monitoring and Remediation}

DOE has developed a plan to accelerate cleanup of Hanford's groundwater, which will return it to its beneficial use where practicable or will at least prevent further degradation. Under the accelerated plan DOE will (a) remediate high-risk waste sites, (b) shrink the contaminated area, (c) reduce recharge, (d) remediate groundwater, and (e) monitor groundwater. The maps on the following pages show the distribution of nine principal groundwater contaminant plumes.

Of the radionuclide plumes, tritium and iodine-129 have the largest areas where concentrations exceed drinking water standards. The dominant plumes had sources in the 200 East Area and extend toward the east and southeast. Extensive tritium and iodine-129 plumes are also present in 200 West Area. Technetium-99 exceeds standards in plumes within both the 200 East and 200 West Areas. One technetium-99 plume has moved northward from the 200 East Area. Uranium is less mobile than tritium, iodine-129, or technetium-99; plumes are found in the 200 East, 200 West, and 300 Areas. Strontium-90 is not very mobile in groundwater, but it exceeds standards in each of the 100 Areas and forms an extensive plume in 100-N Area. Other radionuclides, including cesium-137, cobalt-60, and plutonium, are even less mobile in the subsurface and exceed drinking water standards in very few wells.

Nitrate is a widespread chemical contaminant in Hanford Site groundwater; plumes originate from the 100 and 200 Areas and from offsite industry and agriculture. Carbon tetrachloride, the most widespread organic contaminant on the Hanford Site, forms a large plume beneath the 200 West Area. Other organic contaminants include chloroform, found in 200 West Area, and trichloroethene. The largest trichloroethene plume is found in 200 West Area with smaller plumes in the 100-K and 100-F Areas. Chromium contamination underlies portions of the 100-K, 100-D, and 100-H Areas. Local plumes of chromium contamination also are present in the 200 Areas, particularly the north part of 200 West Area.

\begin{tabular}{|c|c|c|}
\hline \multicolumn{3}{|c|}{ Groundwater Remediation } \\
\hline Remedial Action Site & Startup Date & Progress From Startup to September 2004 \\
\hline 100-K Area - 100-KR-4 Pump-and-Treat & 1997 & Decreases chromium to river; 244 kilograms removed. \\
\hline 100-N Area - 100-NR-2 Pump-and-Treat & 1995 & $\begin{array}{l}\text { Diverts strontium-90 from river; } 1.6 \text { curies removed; } ~ 12 \text { curies } \\
\text { decayed naturally. }\end{array}$ \\
\hline 100-D Area - 100-HR-3 Pump-and-Treat & 1997 & Decreases chromium to river; 199 kilograms removed. \\
\hline 100-D Area - 100-HR-3 In Situ Redox & 1999 & Decreases chromium concentrations downgradient of barrier. \\
\hline 100-H Area - 100-HR-3 Pump-and-Treat & 1997 & Decreases chromium to river; 37 kilograms removed. \\
\hline 200 West Area - 200-ZP-1 Pump-and-Treat & 1994 & $\begin{array}{l}\text { Prevents high-concentration portion of carbon tetrachloride } \\
\text { plume from spreading; } 8,508 \text { kilograms removed. }\end{array}$ \\
\hline 200 West Area - Soil-Vapor Extraction & 1992 & $\begin{array}{l}\text { Prevents carbon tetrachloride movement to groundwater; } \\
78,300 \text { kilograms removed. }\end{array}$ \\
\hline 200 West Area - 200-UP-1 Pump-and-Treat & 1994 & $\begin{array}{l}\text { Decreases migration of contaminants; } 114 \text { grams technetium- } 99 \\
\text { ( } 2.39 \text { curies) and } 203 \text { kilograms uranium removed. }\end{array}$ \\
\hline $\begin{array}{l}\text { Waste Management Area S-SX - } \\
\text { Well 299-W23-19 Pump-and-Treat }\end{array}$ & 2003 & 0.11 grams (0.0019 curies) of technetium-99 removed. \\
\hline 300 Area - 300-FF-5 Natural Attenuation & $\begin{array}{c}\text { Not } \\
\text { applicable }\end{array}$ & $\begin{array}{l}\text { Average trichloroethene concentrations below target level; } \\
\text { uranium concentrations above target level. }\end{array}$ \\
\hline 1100-EM-1 - Natural Attenuation & $\begin{array}{c}\text { Not } \\
\text { applicable }\end{array}$ & $\begin{array}{l}\text { Average trichloroethene concentrations below } 5 \mu \mathrm{g} / \mathrm{L} \text { since } \\
2001 \text {. }\end{array}$ \\
\hline
\end{tabular}




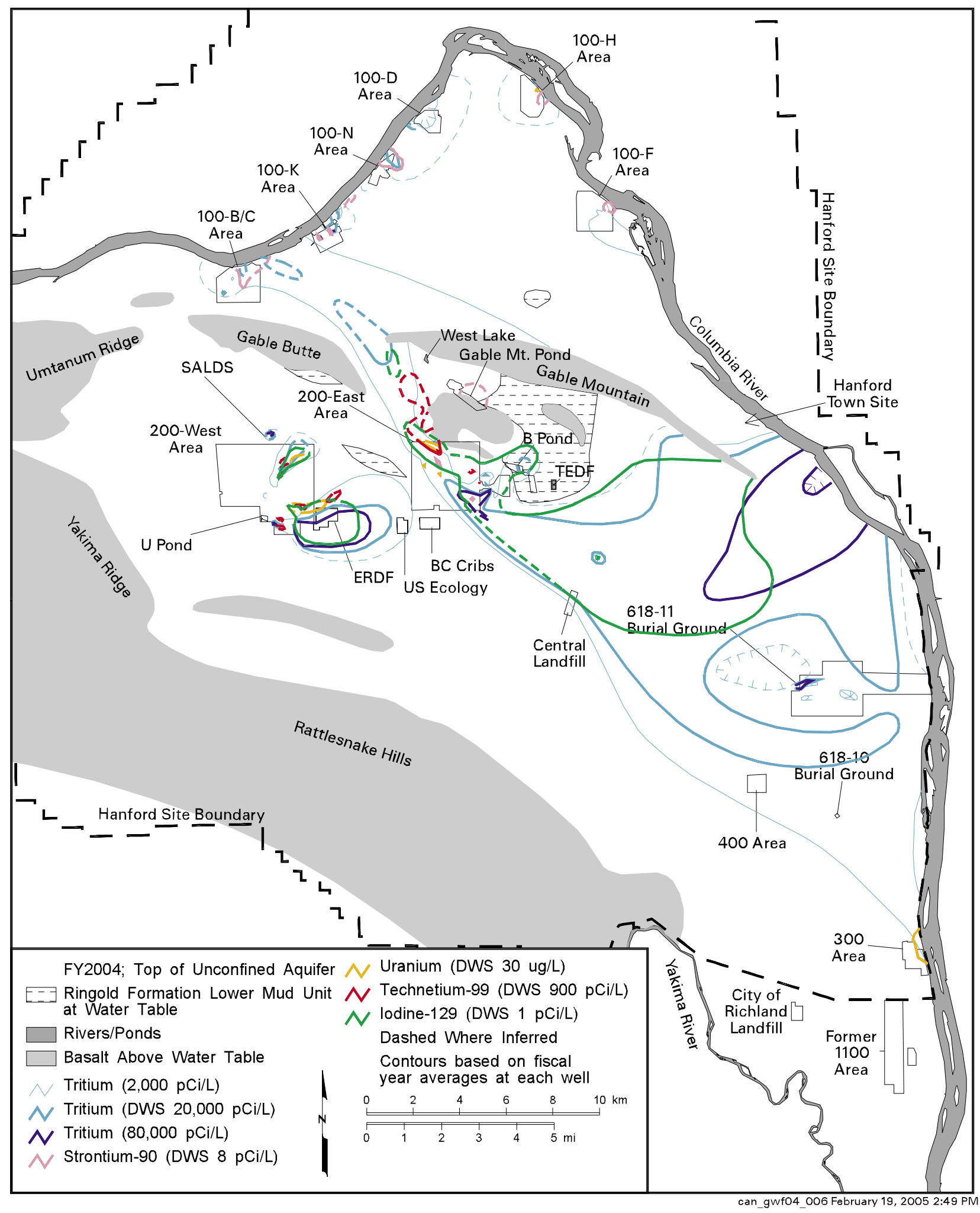

This map shows the distribution of radionuclides in groundwater at concentrations above drinking water standards during FY 2004 at the top of the unconfined aquifer. 


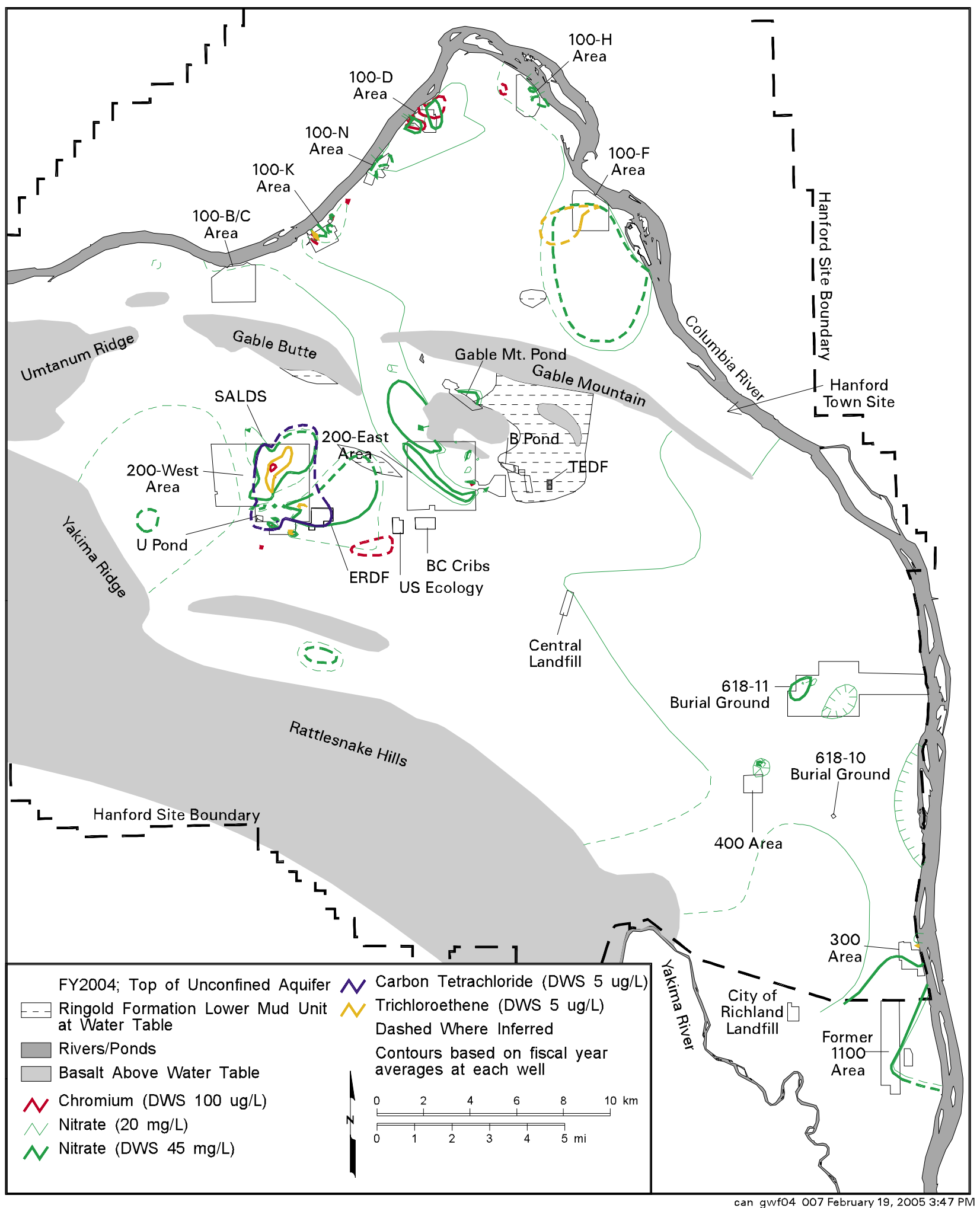

This map shows the distribution of hazardous chemicals in groundwater at concentrations above drinking water standards during FY 2004 at the top of the unconfined aquifer. 


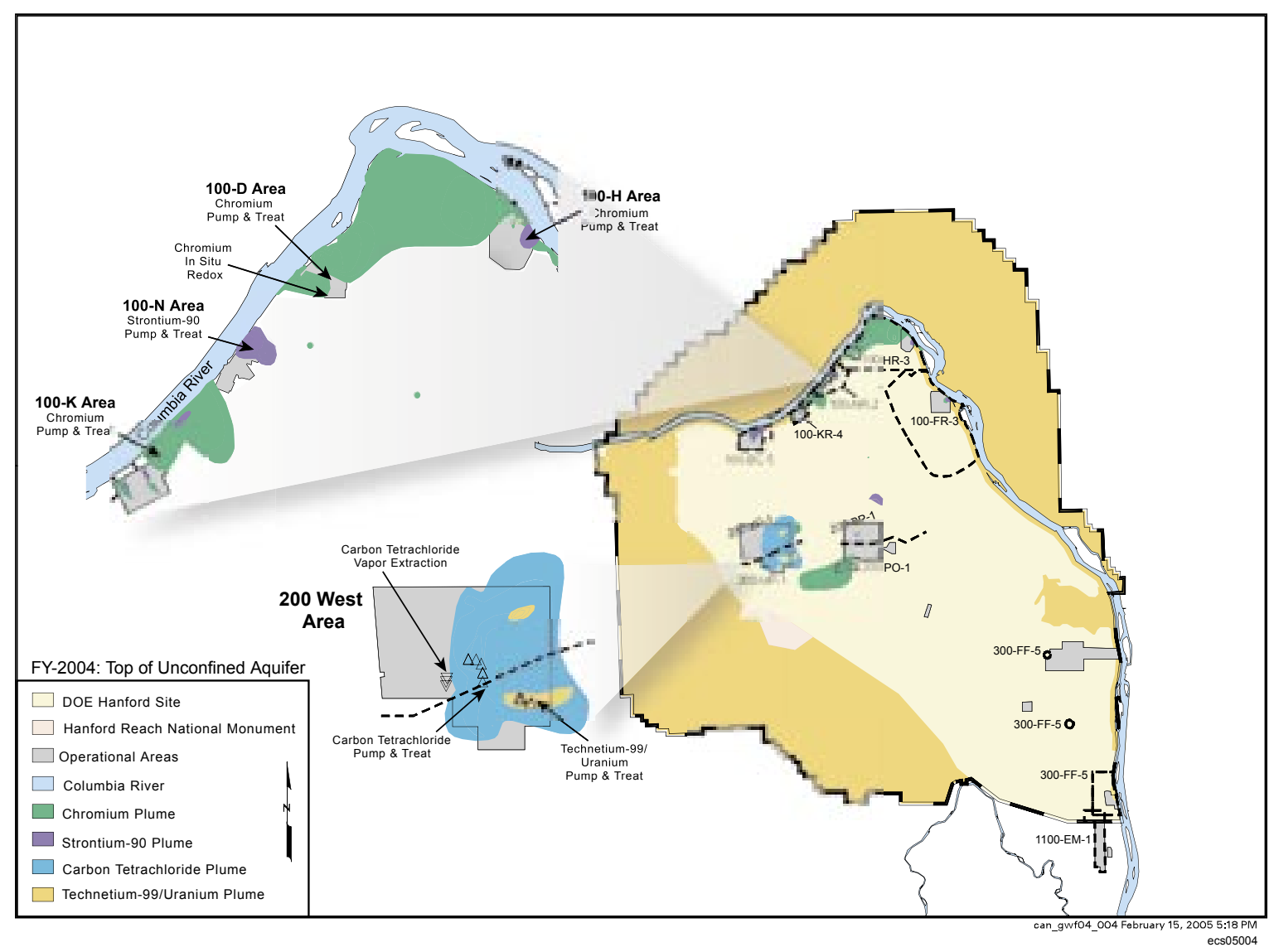

DOE operates six pump-and-treat systems, one in situ remediation system, and one soil-gas extraction system to remove contaminants and limit their movement in groundwater and the vadose zone.

\begin{tabular}{|c|c|c|c|c|c|}
\hline \multicolumn{6}{|c|}{ Area of Contaminant Plumes at Levels Above Drinking Water Standards (square kilometers)(a) } \\
\hline $\begin{array}{c}\text { Constituent } \\
\text { (drinking water standard) }\end{array}$ & $\begin{array}{l}\text { Fiscal Year } \\
2000\end{array}$ & $\begin{array}{l}\text { Fiscal Year } \\
2001\end{array}$ & $\begin{array}{l}\text { Fiscal Year } \\
2002\end{array}$ & $\begin{array}{l}\text { Fiscal Year } \\
2003\end{array}$ & $\begin{array}{l}\text { Fiscal Year } \\
2004\end{array}$ \\
\hline Carbon tetrachloride $(5 \mu \mathrm{g} / \mathrm{L})$ & 9.8 & 9.9 & 10.0 & 10.6 & 10.9 \\
\hline Chromium (100 pg/L) & 2.8 & 2.8 & 2.6 & 2.6 & 2.3 \\
\hline lodine-129 (1 pCi/L) & 89.7 & $79.5^{(b)}$ & 79.4 & 75.5 & 74.4 \\
\hline Nitrate (45 mg/L) & 36.3 & 38.4 & 35.7 & 36.3 & $42.2^{(b)}$ \\
\hline Strontium-90 (8 pCi/L) & 2.8 & 2.7 & 2.7 & 2.6 & 2.6 \\
\hline Technetium-99 (900 pCi/L) & 2.3 & 2.4 & 2.3 & 2.3 & 2.4 \\
\hline Trichloroethene (5 $\mu \mathrm{g} / \mathrm{L})$ & 4.2 & 4.3 & $3.4^{(b)}$ & 3.4 & 3.3 \\
\hline Tritium $(20,000 \mathrm{pCi} / \mathrm{L})$ & 176 & 175 & 166 & 160 & 138 \\
\hline Uranium $(20 / 30 \mu g / L)^{(c)}$ & 2.0 & 1.6 & 1.5 & 1.4 & 1.3 \\
\hline Combined Plumes & 232 & 232 & 220 & 214 & 171 \\
\hline \multicolumn{6}{|c|}{$\begin{array}{l}\text { (a) An error in the algorithm used to compute the areas of some site plumes was discovered during preparation of this } \\
\text { report. Area estimates in this table were corrected from those in previous annual reports where necessary. } \\
\text { (b) These large changes in estimates of plume area are caused by changing interpretations of the data and changes to the } \\
\text { monitoring network. Changes in actual plume size are usually more gradual. } \\
\text { (c) Area of uranium plume based on } 20 \mathrm{mg} / \mathrm{L} \text { standard in } 2000 \text { and } 30 \mathrm{mg} / \mathrm{L} \text { standard in subsequent years. }\end{array}$} \\
\hline
\end{tabular}


The following text discusses groundwater contamination, monitoring, and remediation for each of the 11 groundwater operable units and in the confined aquifers.

\section{0-BC-5 Operable Unit}

This operable unit includes the groundwater beneath the 100-B/C Area, located in the northwest Hanford Site. Most of the groundwater contamination is found in the north portion of the area, beneath former waste trenches and retention basins. Tritium and strontium-90 exceeded drinking water standards in several wells. Nitrate and chromium were somewhat elevated, but have been below drinking water standards in recent years.

New aquifer tubes were installed in FY 2004 to improve monitoring coverage at the Columbia River shoreline. The sampling and analysis plan was revised for use in FY 2005, slightly altering the monitoring network based on data collected or interpreted after implementation of the previous plan.

A record of decision has not yet been developed for the 100-BC-5 Operable Unit, and no active remediation of groundwater is underway. Monitoring contaminant conditions has continued since the initial remedial investigation and while waste site remedial actions are conducted. A pilot-scale test ecological risk investigation was started in FY 2004, which will serve as a prototype for the other reactor areas. A focused feasibility study, which looks at remedial action alternatives for groundwater, will start in FY 2005.

\section{0-KR-4 Operable Unit}

The principal groundwater issues in this operable unit include (a) remediation of groundwater beneath a large liquid-waste disposal trench; (b) tracking plumes from other past-practices sites; and (c) monitoring groundwater near the KE and KW Basins. Interim
DOE is planning

feasibility studies

in the 100-BC-5,

100-FR-3, and

300-FF-5 Operable

Units to support

final cleanup

decisions.
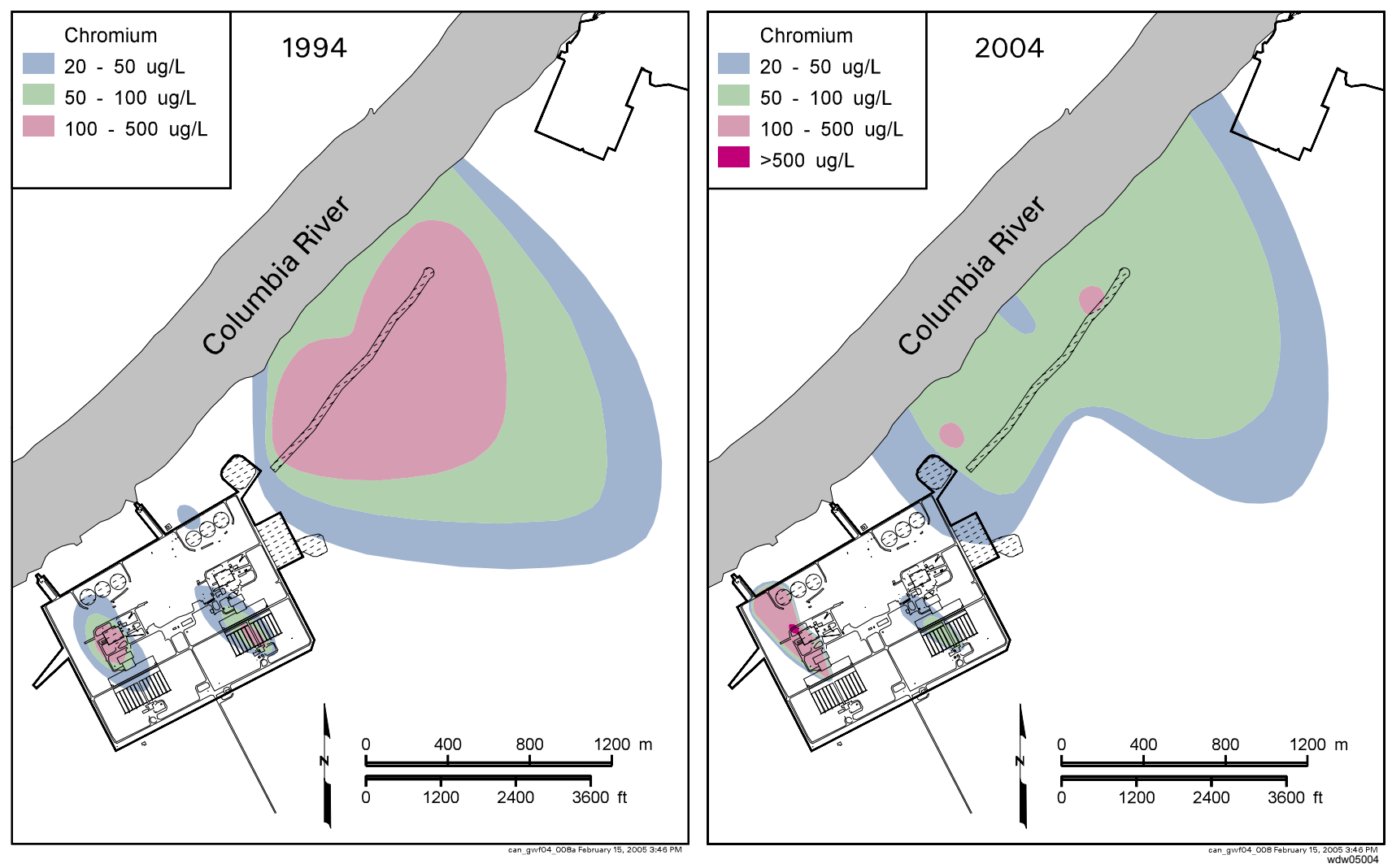

These maps show chromium at the top of the unconfined aquifer in the 100-K Area. A pump-and-treat system reduces the amount of chromium entering the Columbia River. Concentrations decreased in most areas since 1994. 


\section{Pump-and-treat technology is not an effective way to clean up strontium-90 contamination. DOE, regulatory agencies, and stakeholders are investigating alternative methods.}

remedial action involves a pump-and-treat system that removes chromium from groundwater beneath the trench. Leakage detection monitoring is underway for the two basins, which are currently undergoing decontamination and decommissioning activities. New monitoring capabilities were added during FY 2004 in the form of additional aquifer tube sites along the $100-\mathrm{K}$ Area shoreline. Two new groundwater wells were installed in calendar year 2004 to support the interim remedial action.

Interim Remedial Action Progress. A pump-and-treat system is being used to remove hexavalent chromium from the aquifer beneath the large infiltration trench. Approximately 244 kilograms of chromium have been removed since startup in 1997, a quantity that represents a significant proportion of the mapped plume. Although the mapped extent of contamination has remained fairly constant during the past 10 years, the area of highest concentrations has decreased markedly. The concentration goal for the interim remedial action is $22 \mu \mathrm{g} / \mathrm{L}$ in groundwater near the Columbia River.

Monitoring Past-Practices Waste Sites. Other contaminants of potential concern in the operable unit are tritium, carbon-14, nitrate, strontium-90, trichloroethene, and tritium. These contaminants are associated with waste disposal and facility operations that occurred during the reactor years (1955 to 1971). While levels remain above drinking water standards, risks to the river ecosystem are deemed low; decisions regarding remedial actions have been deferred until source remedial actions are complete. Some recent variability in contaminant concentrations is believed to be caused by remobilization of contaminants held in the vadose zone, because of infiltrating water from the ground surface, or possibly because of activities associated with remedial actions (e.g., excavation) of waste sites.

$\mathrm{K}$ Basins. The KE and KW Basins are integral parts of each reactor building. Since the late 1970s, they have been used to store irradiated fuel from the last run of N Reactor, as well as miscellaneous fuel fragments recovered from cleanup at other reactor areas. The Spent Nuclear Fuels Project completed removal, repackaging, and transport of all fuel from the basins to Central Plateau storage in fall 2004 and is now engaged in removing the highly contaminated sludge from the basin floors. Groundwater monitoring is conducted to help detect and evaluate any potential loss of water from the basins to the ground, because the remaining shielding water is also highly contaminated with radionuclides. The last well-documented leakage of shielding water occurred in 1993 from a construction joint associated with the KE Basin. There has been no documented leakage from KW Basin.

\section{0-NR-2 Operable Unit}

The primary groundwater contaminant in the 100-N Area is strontium-90, which originated at two liquid waste disposal cribs. The extent of the plume has changed little in over 12 years; however, concentrations increased during the 1990s because of changing water levels caused by fluctuating Columbia River levels. Tritium also was present in waste discharged to the 100-N Area cribs. Tritium concentrations in groundwater are declining, and the plume is shrinking. Nitrate, sulfate, and petroleum hydrocarbons also are present in 100-N Area groundwater.

Interim Remedial Action. A pump-and-treat system in the 100-N Area operates as a CERCLA interim action to reduce the movement of strontium-90 toward the Columbia River. Since strontium-90 binds to sediment grains, pump-and-treat technology is not an effective way to clean up the aquifer. Concentrations remained far above the drinking water standard in FY 2004. The system creates a hydraulic barrier to flow, thereby decreasing groundwater flow into the Columbia River. DOE is investigating alternative methods for remediation of the strontium-90 plume: phytoremediation (plants) and a permeable reactive barrier in the aquifer. In anticipation of applying the new methods, DOE increased sampling frequency beginning in FY 2004 and installed three new monitoring wells and new aquifer tubes along the 100-N Area shoreline to collect baseline data.

116-N-1, 116-N-3, 120-N-1, and 120-N-2 (1301-N, 1325-N, 1324-N/NA) Facilities. Four RCRA units are located in the 100-N Area. During FY 2004, the sites remained in 

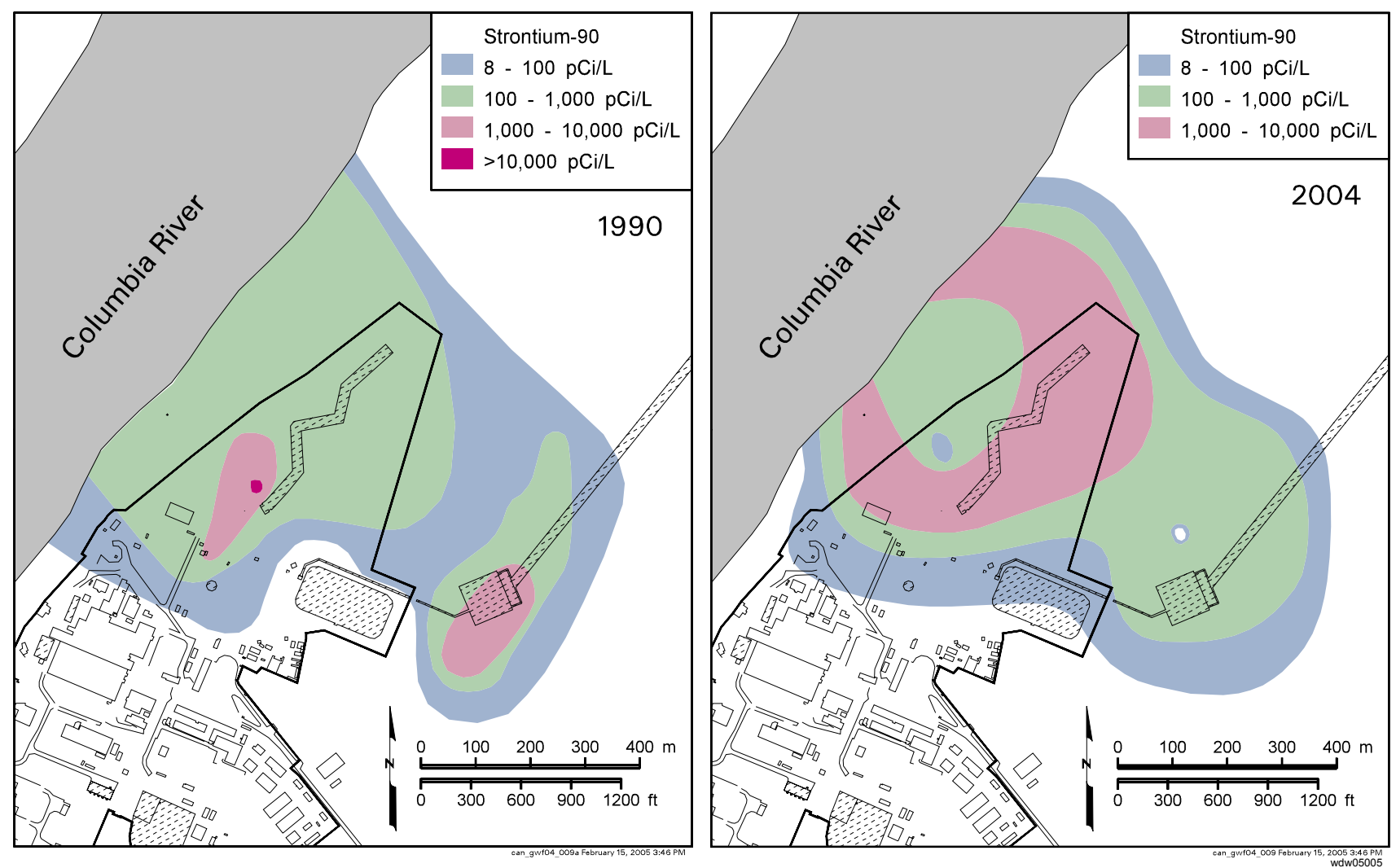

Concentrations of strontium-90 in some parts of the 100-N Area increased after 1990, but the overall shape of the plume at the top of the aquifer remained about the same in 2004.

detection monitoring programs. AEA monitoring continued to track strontium-90 and tritium plumes from the $116-\mathrm{N}-1$ and $116-\mathrm{N}-3$ facilities and sulfate from the $120-\mathrm{N}-1$ pond.

\section{0-HR-3-D Operable Unit}

The 100-HR-3 Operable Unit underlies the 100-D and 100-H Areas and the region between. Hexavalent chromium is the primary contaminant of concern in the 100-D Area (100-HR-3-D), which comprises the west part of the operable unit. The source of this contaminant was sodium dichromate added to reactor cooling water to inhibit corrosion, which was discharged to cribs and ditches. Chromium is distributed in two plumes. Other contaminant plumes include tritium, nitrate, and sulfate.

Interim Remedial Actions. The north chromium plume is the target of a pump-and-treat system, which is designed to reduce the amount of chromium entering the Columbia River. In FY 2004, concentrations remained above the remediation goal $(22 \mu \mathrm{g} / \mathrm{L})$ in compliance wells. DOE installed a second pump-and-treat system in FY 2004 to intercept groundwater in the central 100-D Area near the shoreline, where chromium concentrations had increased in recent years. The southwest chromium plume is being remediated with an in situ system that immobilizes chromium in the aquifer. Chromium concentrations downgradient of the remediation system have declined in some wells and aquifer tubes, but levels remained above the remediation goal $(20 \mu \mathrm{g} / \mathrm{L})$. Three new wells and new aquifer tubes were installed in 2004 to support the interim remedial actions.

Chromium Sensor. DOE deployed a chromium sensor on the 100-D Area shoreline in FY 2004. The purpose of the deployment was to demonstrate the efficacy of such a system in the field. The system can measure chromium concentrations in monitoring wells and 

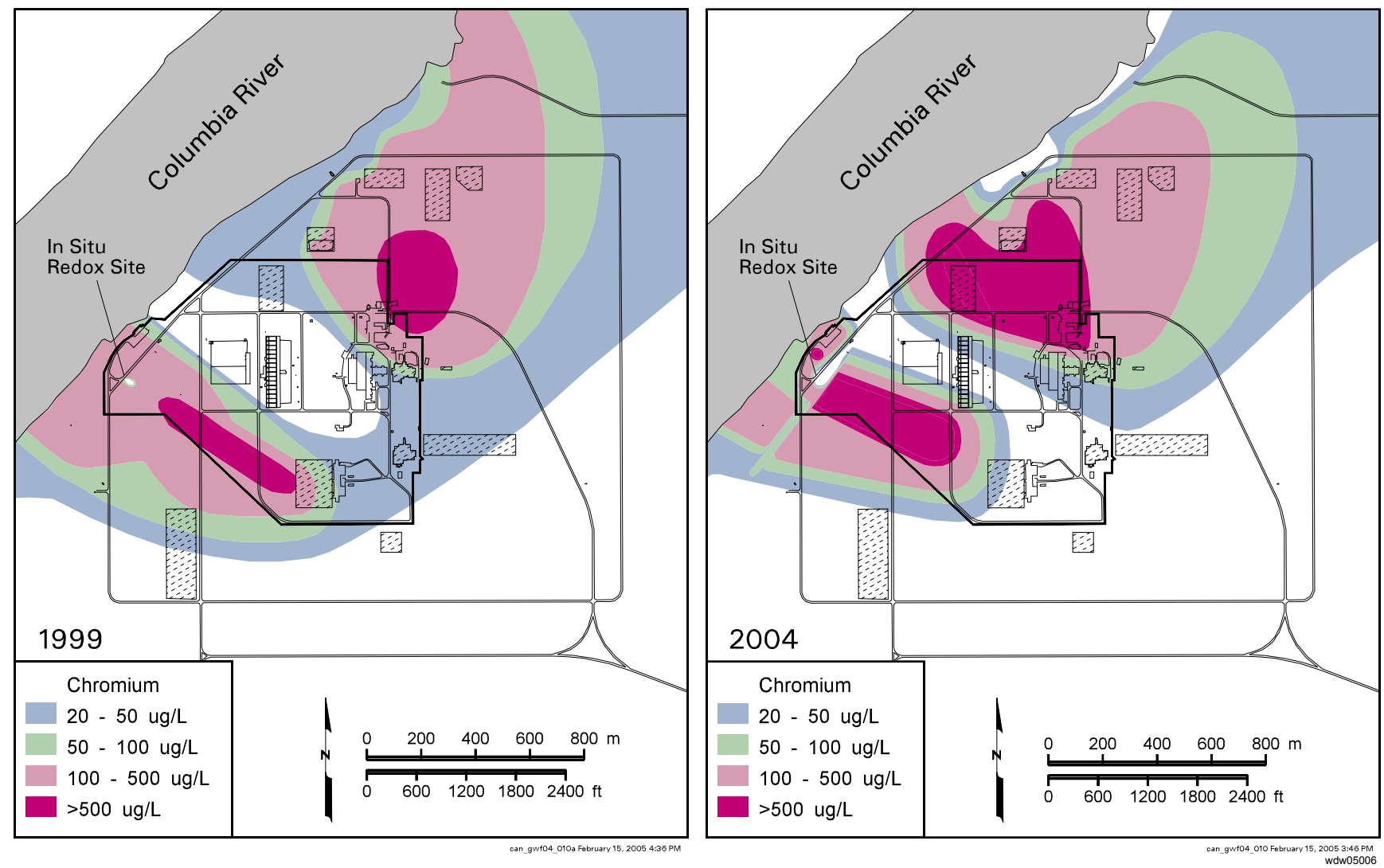

These maps show chromium plumes at the top of the aquifer in the 100-D Area. To decrease the amount of chromium entering the Columbia River, DOE operates two pump-and-treat systems in the north and an in situ treatment system in the south. One of the pump-and-treat systems was added in FY 2004.

\section{Chromium}

concentrations in

100-H Area have

declined due to

remediation and

natural processes. aquifer tubes at more frequent intervals than is practical using manual sampling techniques, and can record and report results immediately. Results of the limited deployment showed that sensors are suitable for shoreline monitoring at the Hanford Site.

\section{0-HR-3-H Operable Unit}

The east part of the 100-HR-3 Operable Unit (100-HR-3-H) underlies the 100-H Area. Hexavalent chromium is the primary constituent of concern, but the plume is smaller and concentrations are lower than in the 100-D Area. Nitrate also is elevated, but concentrations have declined from their peak levels. Strontium-90 exceeds the drinking water standard beneath former retention basins. Technetium-99 and uranium are elevated in a small area.

Interim Remedial Action. The chromium plume is the target of a pump-and-treat system. Chromium concentrations have decreased in recent years due to remediation and natural processes. However, concentrations in some compliance wells remained above the remediation goal $(22 \mu \mathrm{g} / \mathrm{L})$. New aquifer tubes were installed in 2004 to improve monitoring coverage along the $100-\mathrm{H}$ Area shoreline.

116-H-6 (183-H) Evaporation Basins. These former basins comprise the only RCRA site in the 100-H Area. Leakage from the basins contaminated groundwater with chromium, nitrate, and the non-RCRA regulated constituents, technetium-99 and uranium. The site is monitored during the post-closure period to track contaminant trends during the operation of the CERCLA interim action for chromium.

Bioremediation Research. DOE conducted field tests near the 100-H Area in FY 2003 and 2004 to demonstrate the feasibility of a remediation technology to immobilize hexavalent 

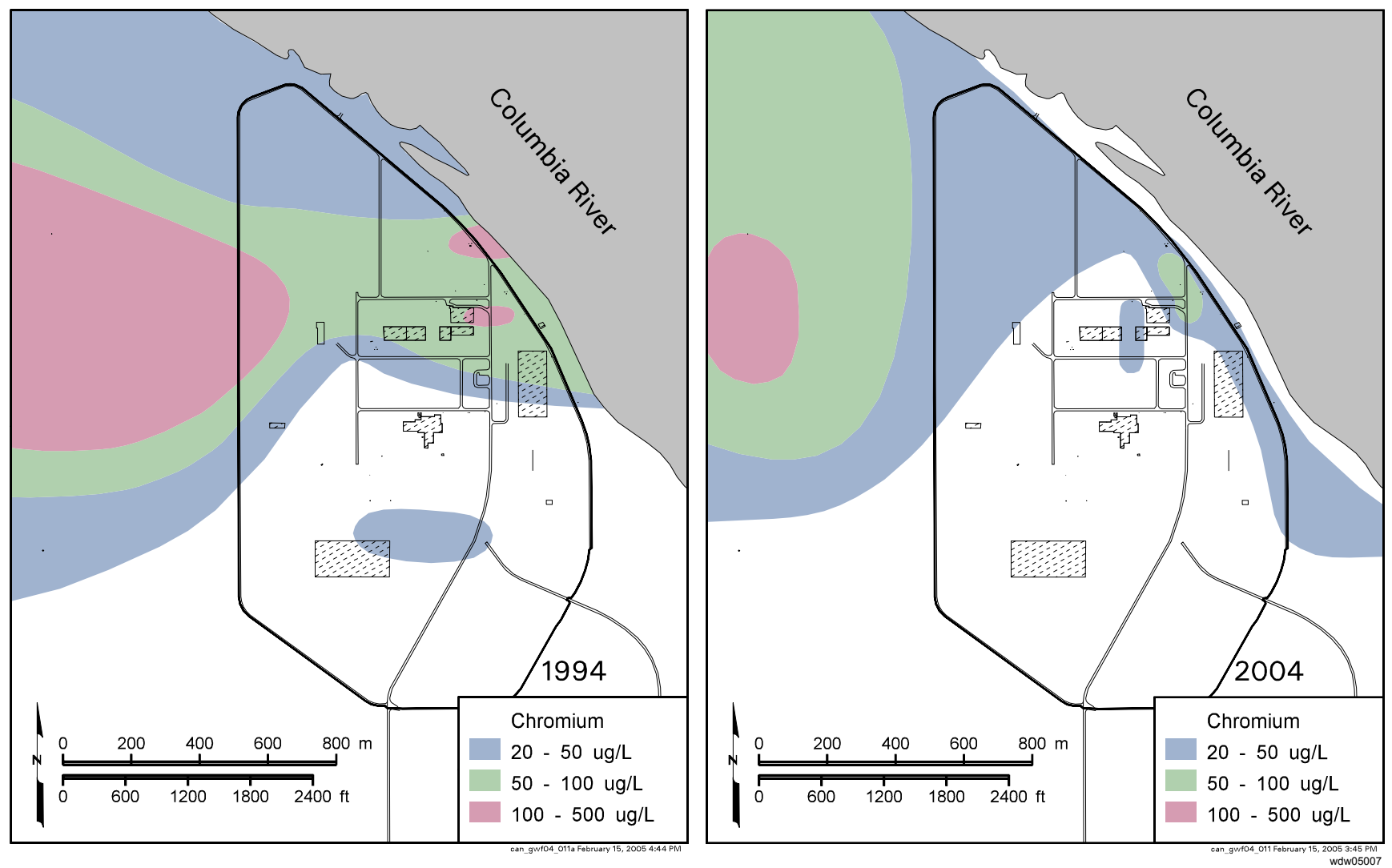

A pump-and-treat system in the 100-H Area reduces the amount of chromium entering the Columbia River. Between 1994 and 2004, concentrations at the top of the aquifer decreased through most of the plume. The decrease is the result of remediation and natural processes.

chromium in the aquifer. Researchers identified several types of bacteria in the sediment, including species that are known to reduce or sorb hexavalent chromium. The natural microbial population is likely insufficient for direct chromium reduction, but the population was successfully stimulated during the field tests.

\section{0-FR-3 Operable Unit}

Nitrate exceeds the drinking water standard beneath much of the 100-F Area and the downgradient region. Other groundwater contaminants include strontium-90 and trichloroethene.

New aquifer tubes were installed in FY 2004 to improve monitoring coverage at the Columbia River shoreline. The sampling and analysis plan was revised for use in FY 2005, slightly altering the monitoring network based on data collected or interpreted after implementation of the previous plan.

A record of decision has not yet been developed for the 100-FR-3 Operable Unit, and no active remediation of groundwater is underway. Monitoring contaminant conditions has continued since the initial remedial investigation and while waste site remedial actions are conducted. A focused feasibility study, which looks at remedial action alternatives for groundwater, will start in FY 2005.

\section{0-ZP-1 Operable Unit}

This operable unit encompasses the north portion of the 200 West Area. The primary contaminant of concern is carbon tetrachloride, which forms the largest plume of chlorinated hydrocarbons on the Hanford Site. The carbon tetrachloride contamination had sources 

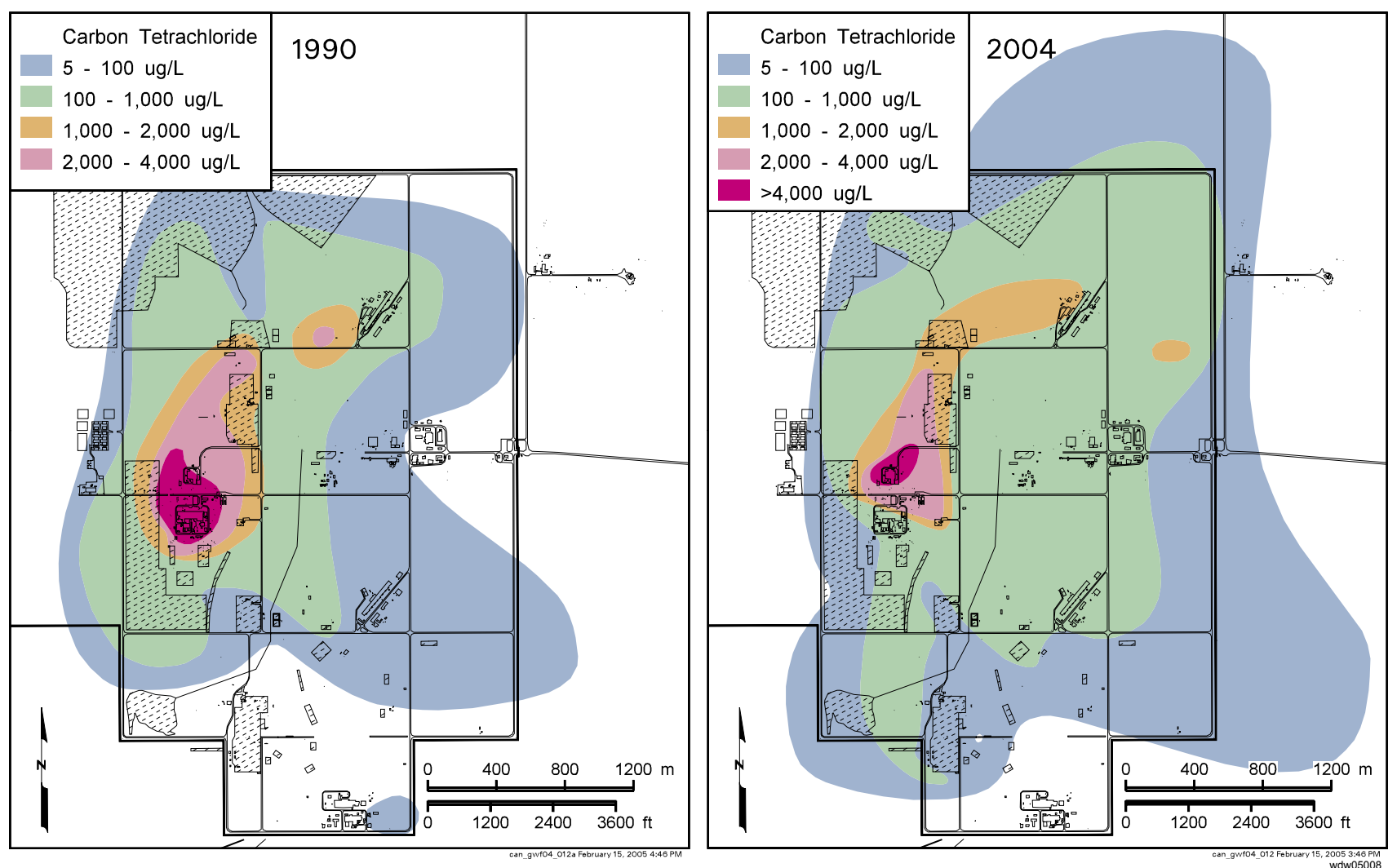

These maps show the carbon tetrachloride plume beneath the 200 West Area at the top of the unconfined aquifer. The edges of the plume spread between 1990 and 2004. Since 1996, a pump-and-treat system in the 200-ZP-1 Operable Unit is helping prevent further spreading of the core of the plume, shown here in pink and red. The system is being expanded to capture the portion of the plume shown in yellow that has appeared north of the existing system.

\section{A pump-and-treat} system prevents

the spread of the high-concentration

portion of the carbon tetrachloride plume beneath the 200-ZP-1 Operable Unit. associated with waste disposal from the Plutonium Finishing Plant, where organic chemicals were used to process plutonium. Trichloroethene and chloroform also are associated with this plume. Other contaminants in the 200-ZP-1 Operable Unit include tritium, nitrate, chromium, fluoride, iodine-129, technetium-99, and uranium.

Carbon tetrachloride has migrated vertically and laterally farther than expected. The distribution of carbon tetrachloride is complex because it may travel as a dense, non-aqueous phase liquid, in the gaseous state, and dissolved in water. Most wells in the 200 West Area are completed at the top of the aquifer, but in recent years, DOE has begun to study carbon tetrachloride deeper in the aquifer. In FY 2004, depth-discrete data collected during drilling of a well in east-central 200 West Area showed carbon tetrachloride concentrations of $32 \mu \mathrm{g} / \mathrm{L}$ near the water table and $1,300 \mu \mathrm{g} / \mathrm{L}$ at the bottom of the unconfined aquifer. Samples collected from the Ringold confined aquifer had lower concentrations, declining to $132 \mu \mathrm{g} / \mathrm{L}$ at the top of basalt. Similar distribution with depth has been observed in other wells, but not ubiquitously. DOE will continue to study the nature and extent of carbon tetrachloride contamination.

The 200-ZP-1 Operable Unit contains one CERCLA interim action for groundwater, one remediation system for the vadose zone, four facilities monitored under RCRA and AEA, and one state-permitted unit.

Interim Remedial Action. Since 1994, DOE has operated an interim action pumpand-treat system to prevent carbon tetrachloride from spreading. More recently, carbon tetrachloride concentrations have been detected above the remedial action goal north of 
the original target area. Because of these changes, plans are now underway to expand the pump-and-treat system by adding additional extraction wells. Also, concentrations near the remedial action goal have been found in the east-central 200 West Area at various depths, suggesting that additional characterization of the deeper aquifer should be performed. Four new wells were installed in 2004 to support the interim remedial action.

Soil-Vapor Extraction. Soil vapor is extracted from the vadose zone and treated to remove carbon tetrachloride. As of October 2004, 78,300 kilograms of carbon tetrachloride have been removed from the vadose zone since extraction operations started in 1991.

Low-Level Burial Grounds Waste Management Areas 3 and 4. RCRA groundwater monitoring continued under interim status requirements in FY 2004. Monitoring networks for both of these waste management areas contain fewer than the optimal number of wells for groundwater monitoring because many wells have gone dry. DOE is working with Ecology to correct the deficiencies.

In June 2002, DOE submitted an application to incorporate the low-level burial grounds into the Hanford Facility RCRA Permit. As part of the application, new groundwater monitoring wells, constituents, and statistical evaluations were proposed. Workshops with Ecology to address Ecology comments (i.e., Notice of Deficiency) on this application began in FY 2003 and continued through 2004.

Waste Management Area T. Results of RCRA assessment and AEA monitoring indicate that the waste management area probably has introduced technetium-99 and other tank waste contaminants to the uppermost aquifer in the area. Additional contamination that is likely from other facilities is present in groundwater beneath the waste management area.

Waste Management Area TX-TY. Results of RCRA assessment and AEA monitoring continued to indicate that sources in the waste management area have contaminated groundwater with chromium and other tank waste constituents. Other nearby sources of contamination make source determinations uncertain for some contaminants. Technetium-99, iodine-129, nitrate, and tritium are elevated in groundwater beneath the area.

State-Approved Land Disposal Site. This active disposal facility is regulated under a state waste discharge permit. Groundwater is monitored for tritium and 15 other constituents. Concentrations did not exceed permit enforcement limits during FY 2004.

\section{0-UP-1 Operable Unit}

This operable unit underlies the south portion of 200 West Area. The primary contaminants of concern are technetium-99 and uranium. Tritium, iodine-129, and nitrate
In FY 2004, depthdiscrete data collected during drilling of a well in east-central 200 West Area showed carbon tetrachloride concentrations were much higher at the bottom of the unconfined aquifer than at the top. High concentrations were not expected in that region, which is not near the contaminant sources.
Dry Monitoring Wells

Some wells that were formerly sampled for the groundwater project have gone dry as the water table declined. Most of the wells are in the 200 West Area.

\begin{tabular}{|c|c|c|c|c|}
\hline Fiscal Year & 200 West & 200 East & Other Areas & Total \\
\hline 1998 & 2 & 1 & 2 & 5 \\
\hline 1999 & 9 & 0 & 1 & 10 \\
\hline 2000 & 12 & 2 & 1 & 15 \\
\hline 2001 & 7 & 0 & 1 & 8 \\
\hline 2002 & 12 & 1 & 1 & 14 \\
\hline 2003 & 6 & 2 & 3 & 11 \\
\hline 2004 & 7 & 1 & 4 & 12 \\
\hline Total & 55 & 7 & 13 & 75 \\
\hline
\end{tabular}


Number of Wells for RCRA Statistical Comparisons, End of FY 2004

Some RCRA sites have insufficient monitoring networks because wells have gone dry. DOE is working with regulatory agencies to determine priorities for installing new wells for RCRA and CERCLA.

$\frac{\text { Site }}{\text { Liquid Effluent Retention Facility }}$
Low-Level Waste Management Area 2
Low-Level Waste Management Area 3
Low-Level Waste Management Area 4
216-S-10 Pond and Ditch
216-U-12 Crib

$\begin{array}{cc}\text { Downgradient } & \text { Upgradient } \\ 1 & 1 \\ 7 & 2 \\ 4 & 2 \\ 0 & 3 \\ 2 & 0 \\ 2 & 0\end{array}$
Comments
Unconfined aquifer too thin to monitor.
No unconfined aquifer in north part of waste management area.
Upgradient wells to be redesignated in FY 2005.

216-U-12 Crib

plumes also have sources in this operable unit. Sources of carbon tetrachloride were within the 200-ZP-1 Operable Unit, but the contamination underlies the 200-UP-1 Operable Unit as well.

There are four facilities monitored under RCRA and AEA, one CERCLA interim action, and a CERCLA disposal site in the 200-UP-1 Operable Unit. Monitoring activities are summarized below.

Interim Remedial Action. A groundwater pump-and-treat system is operating near U Plant to contain the technetium-99 and uranium plumes there. In FY 2004, concentrations in all the extraction and monitoring wells were below the remediation goals. However, many of the wells monitoring this area have gone dry, so the sizes of the current plumes

A groundwater pump-and-treat

system is operating

near U Plant

to contain the

technetium-99 and

uranium plumes

there. The high

concentration

portions of the

plumes were

hydraulically

contained. are uncertain. Seven new wells were installed in the 200-UP-1 Operable Unit in calendar year 2004.

Waste Management Area S-SX. RCRA assessment and AEA monitoring continued in FY 2004. Groundwater beneath this waste management area is contaminated with nitrate, hexavalent chromium, and technetium-99 attributed to two general source areas within the waste management area. One well with very high technetium-99 concentrations continued to be purged at least 3,785 liters after each quarterly sampling event, as Ecology requested in FY 2003.

Waste Management Area U. RCRA assessment and AEA monitoring continued in FY 2004. The waste management area has been identified as the source for a small contaminant plume that is limited to the downgradient (east) side of the site. Plume constituents of interest include chromium, nitrate, and technetium-99. One new well was installed at this waste management area in 2004.

216-U-12 Crib. RCRA assessment and AEA monitoring continued in FY 2004. The crib is one of several sources that have contributed to nitrate and technetium-99 plumes in the area. Closure of the crib will be coordinated between RCRA and CERCLA. The monitoring network contains just two useable downgradient wells and no upgradient wells because other wells have gone dry.

216-S-10 Pond and Ditch. The 216-S-10 facility continued to be monitored under a RCRA interim status detection program in FY 2004. The current RCRA monitoring network consists of only two downgradient wells because other wells have gone dry.

Environmental Restoration Disposal Facility. This facility is a low-level, mixed waste facility where waste from surface remedial actions on the Hanford Site is disposed. The site is designed to meet RCRA standards, although it is not permitted as a RCRA unit. Results of groundwater monitoring continued to indicate that the facility has not adversely impacted groundwater quality. Concentrations of gross beta and unfiltered chromium in groundwater declined from those observed in FY 2003. 

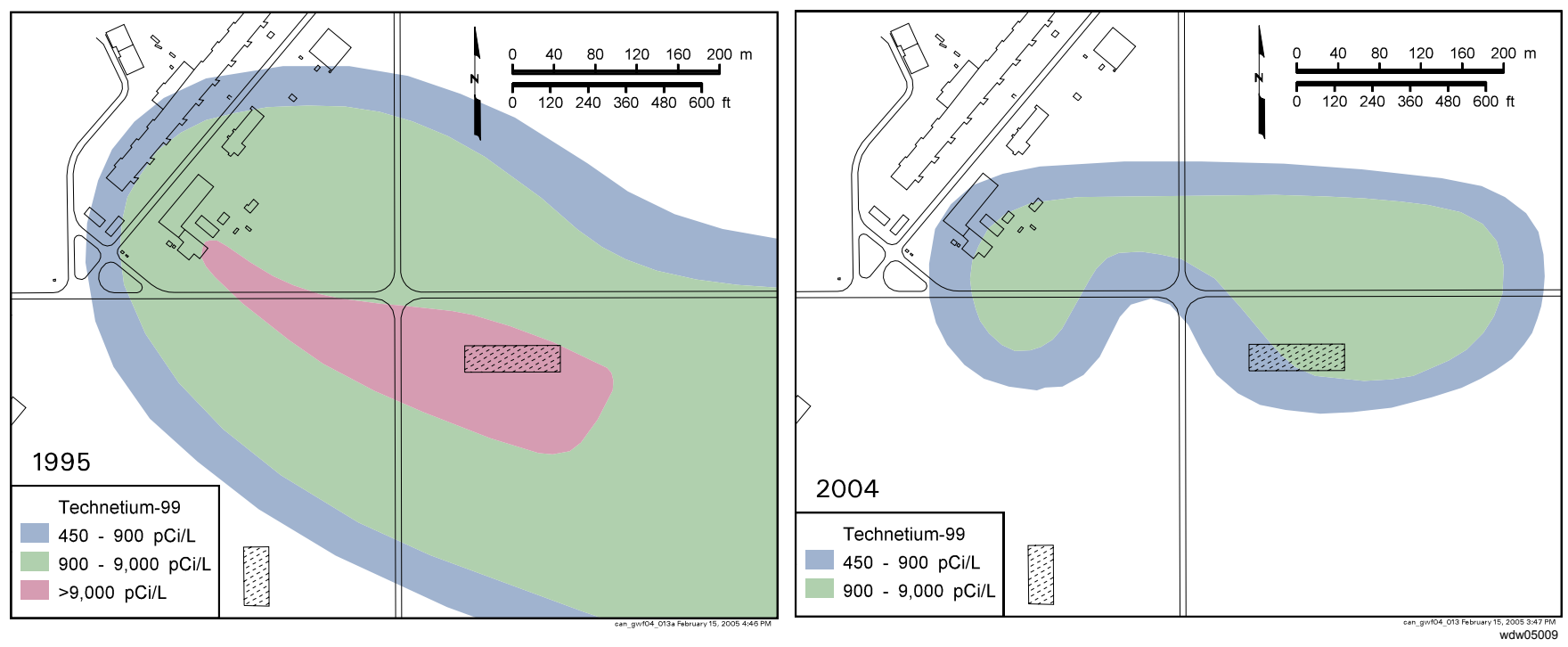

A pump-and-treat system at the 200-UP-1 Operable Unit (200 West Area) has decreased the size of the technetium-99 plume at the top of the aquifer. The system began to operate in fall 1995. DOE plans to conduct a rebound study in FY 2005.
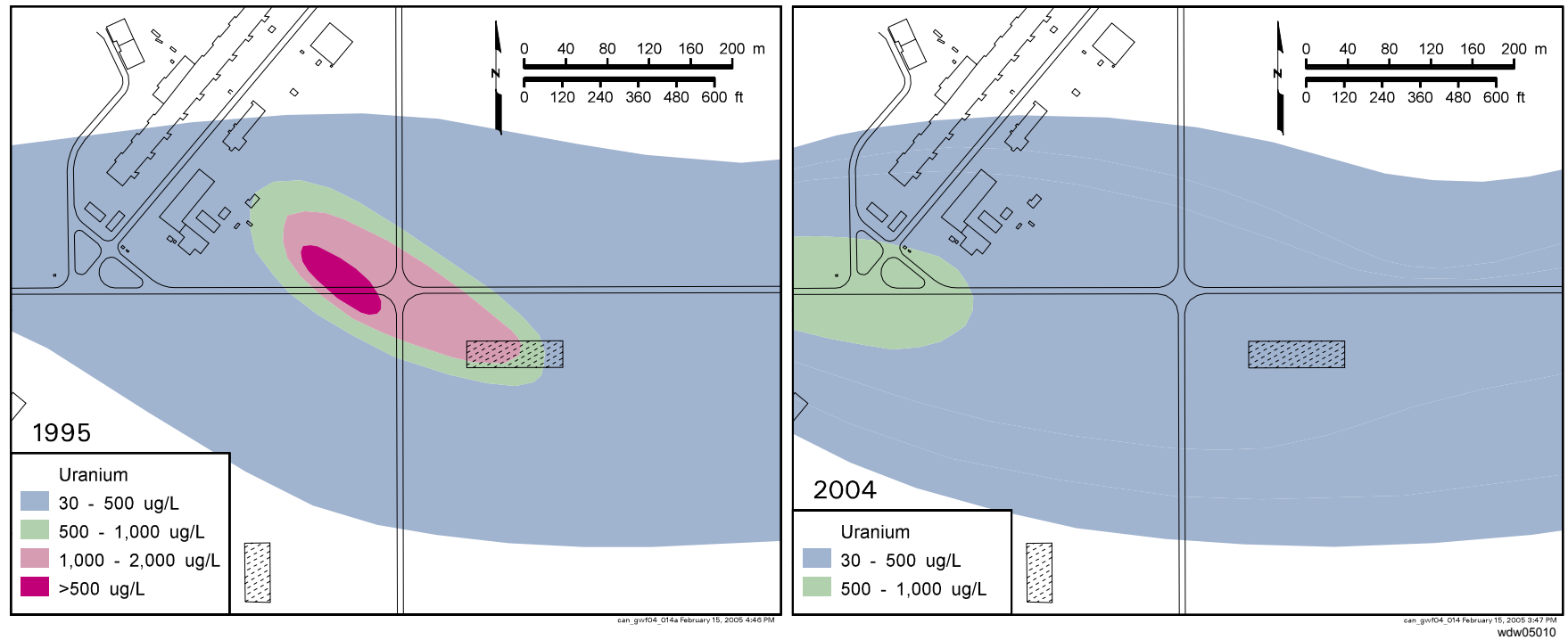

Uranium contamination in the 200-UP-1 Operable Unit (200 West Area), although now below the remedial action goal, did not respond to the pump-and-treat system as quickly as the technetium-99. Unlike technetium-99, uranium interacts with sediment grains, slowing its movement and response to remediation.

\section{0-BP-5 Operable Unit}

This operable unit includes groundwater beneath the north 200 East Area. Technetium-99 and tritium plumes extend northward between Gable Mountain and Gable Butte. Other contaminants include cesium-137, cobalt-60, cyanide, iodine-129, nitrate, plutonium, strontium-90, and uranium.

Groundwater monitoring under CERCLA continued in FY 2004. The sampling and analysis plan was revised to integrate AEA monitoring with CERCLA monitoring for FY 2005 monitoring. There is no active groundwater remediation in this operable unit and final remediation decisions are yet to be made. 


\section{A plume containing tritium, nitrate, and technetium-99 extends from the 200 East Area to the north, as far as the Columbia River.}

\section{Tritium concentrations generally are decreasing southeast of the 200 East Area.}

There are five facilities in the 200-BP-5 Operable Unit that are monitored under RCRA and the AEA. Monitoring activities are summarized below.

Waste Management Area B-BX-BY. RCRA assessment and AEA monitoring continued at this site in FY 2004. Uranium, technetium-99, nitrate, sulfate, and nitrite contamination observed in downgradient wells is believed to be due to vertical movement of residual waste left in the soil under the tank farms. Three new wells were installed at this waste management area in calendar year 2004.

Waste Management Area C. This site continued to be monitored under AEA and an interim status RCRA detection program in FY 2004. RCRA indicator parameters did not exceed critical mean values. However, technetium-99 and nitrate are elevated in groundwater beneath the waste management area and may have originated in the tank farm.

216-B-63 Trench. This site continued to be monitored under an interim status RCRA detection monitoring program. The average value for total organic carbon in one downgradient well was higher in April 2004 than in previous samples. However, the value was below the limit of quantitation $(1,520 \mu \mathrm{g} / \mathrm{L})$, so the results did not trigger assessment monitoring. The well was sampled in October 2004 and no total organic carbon was detected $(<390 \mu \mathrm{g} / \mathrm{L})$.

Low-Level Waste Management Areas 1 and 2. These sites continued to be monitored under RCRA interim status requirements and AEA. Specific conductance continued to exceed its critical mean value at Low-Level Waste Management Area 1, and total organic carbon continued to exceed its critical mean value in an upgradient well at Low-Level Waste Management Area 2. However, both exceedances were reported previously and neither appears to indicate contamination from the burial grounds. Most wells in the north part of Low-Level Waste Management Area 2 are dry, and the water table has dropped below the top of basalt.

In June 2002, DOE submitted an application to incorporate the low-level burial grounds into the Hanford Facility RCRA Permit. As part of the application, new groundwater monitoring wells, constituents, and statistical evaluations are proposed. Workshops with Ecology to address comments (i.e., Notice of Deficiency) on this application began in FY 2003 and continued through 2004.

Liquid Effluent Retention Facility. A 2001 letter from Ecology directed DOE to discontinue statistical evaluation of groundwater sample results because all but two wells have gone dry and a 1999 variance to allow DOE to operate the remaining network expired. DOE has continued to sample the two remaining wells but is not conducting statistical analyses of the results. DOE and Ecology are pursuing an agreement for permit conditions for environmental monitoring.

\section{0-PO-1 Operable Unit}

This operable unit encompasses the south portion of the 200 East Area and a large portion of the Hanford Site extending to the east and southeast that is contaminated with plumes of tritium, nitrate, and iodine-129. Concentrations of tritium continued to decline as the plume attenuates naturally due to radioactive decay and dispersion. Other contaminants include strontium-90 and technetium-99, but these are limited to very small areas.

CERCLA groundwater monitoring continued in FY 2004. There is no active groundwater remediation in this operable unit and final remediation decisions are yet to be made.

There are eight regulated units in the 200-PO-1 Operable Unit. Water supply wells in the 400 Area, which falls within the footprint of the 200-PO-1 Operable Unit, also are monitored.

Integrated Disposal Facility. This planned facility will be an expandable, lined, RCRAcompliant landfill. The groundwater monitoring network will consist of three upgradient wells and five downgradient wells. Three wells remain to be installed; two will be installed in FY 2005; the third will be installed at a future date when required by facility expansion. 
PUREX Cribs. Three cribs (216-A-10, 216-A-36B, and 216-A-37-1) are monitored jointly under a RCRA interim status assessment program and AEA. The cribs have contributed to widespread contaminant plumes in the area, including nitrate, tritium and iodine-129. The nitrate and tritium plumes are generally attenuating throughout most of their area. However, in recent years the concentration of nitrate in near-field wells at the PUREX cribs has either held steady or increased.

Waste Management Area A-AX. This site continued to be monitored under a RCRA interim status indicator evaluation program and AEA in FY 2004. In FY 2004, one additional upgradient well and a replacement downgradient well were installed. Two downgradient wells formerly monitored for this site were decommissioned after it was confirmed with a borehole video survey that each well suffered from extensive corrosion of the casing. FY 2004 data from a downgradient well installed in FY 2003 showed elevated nitrate and technetium-99. DOE is conducting additional studies to determine if the cause of the contamination is the waste management area.

216-A-29 Ditch. The groundwater beneath this site continued to be monitored as required by RCRA interim status detection regulations. Except for specific conductance, RCRA indicator parameters in downgradient wells did not exceed critical mean values in FY 2004. Specific conductance exceeded its critical mean value in three downgradient wells as groundwater quality returns to ambient conditions in response to the cessation of effluent disposal at B Pond. Groundwater quality beneath the ditch closely resembles regional patterns.

216-B-3 Pond. Monitoring for this site returned to a conventional RCRA interim status detection monitoring program in FY 2004. This change marked the end of a trial period for an alternate approach to groundwater monitoring and statistical analysis at the site.
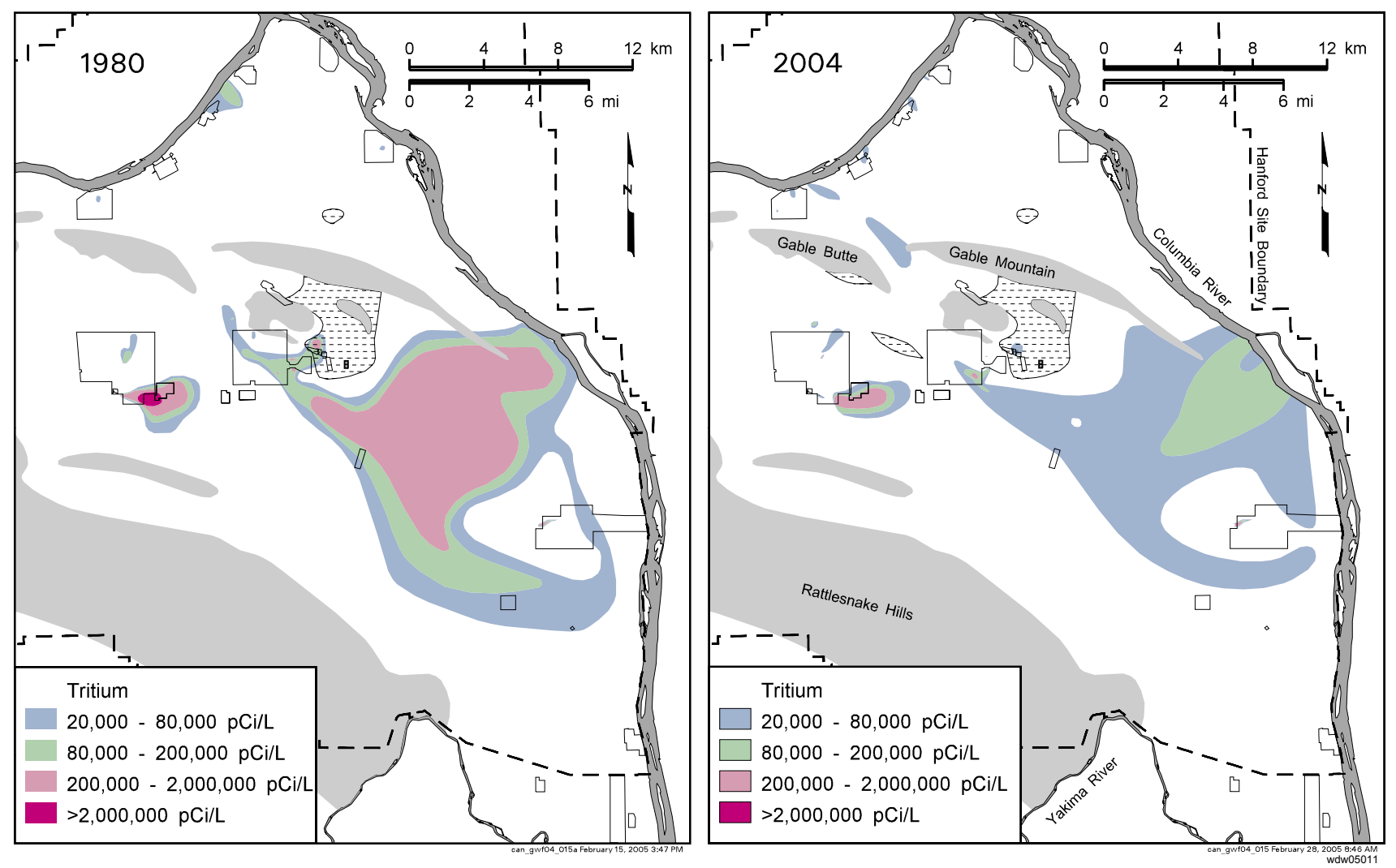

These maps show site-wide tritium plumes at the top of the unconfined aquifer in 1980 and 2004. Concentrations in the core of the plume have decreased over the years; the south margin has ceased its southward migration. 


\section{Uranium beneath}

the 300 Area

has persisted above drinking

water standards

longer than

expected. DOE is

supporting detailed

investigations of

plume behavior and

remedial action

alternatives.
200 Area Treated Effluent Disposal Facility. A state waste discharge permit governs groundwater sampling and analysis in the three monitoring wells at this facility. No permit criteria for constituents in groundwater were exceeded in FY 2004. The groundwater monitoring network continues to show that effluent from the facility is not taking a direct route to the uppermost aquifer, which is confined.

Nonradioactive Dangerous Waste Landfill. This RCRA site is located in the 600 Area, within the footprint of the 200-PO-1 regional plume. Interim status detection monitoring continued FY 2004.

Solid Waste Landfill. This facility is adjacent to the Nonradioactive Dangerous Waste Landfill and is regulated under state solid waste regulations. In FY 2004, temperature, specific conductance, $\mathrm{pH}$, total organic carbon, chemical oxygen demand, chloride, sulfate, and coliform bacteria exceeded their background threshold levels in one or more samples.

400 Area Water Supply Wells. Three water supply wells provide drinking water and emergency supply water for the 400 Area. Because the 400 Area lies in the path of the sitewide tritium plume, the wells are routinely monitored for tritium. The main water supply well is completed deep in the unconfined aquifer and has low tritium values. Two backup wells are shallower and have higher tritium levels, but tritium concentrations in all samples were below the drinking water standard in FY 2004.

\section{0-FF-5 Operable Unit}

This operable unit includes three geographic subdivisions: the 300 Area, the 618-11 burial ground region, and the 316-4 cribs/618-10 burial ground region (the latter two regions are referred to as "300-FF-5 North"). The operable unit is currently regulated under a record of decision that calls for continued monitoring of groundwater conditions and institutional controls on the use of groundwater as an interim action, until source remedial actions are complete. The operable unit includes groundwater associated with a former liquid waste disposal site; that groundwater is also regulated under a RCRA final status, corrective action monitoring program.

Status of Interim Remedial Actions. Contaminants of concern in 300 Area groundwater are uranium, trichloroethene, and cis-1,2-dichloroethene. Monitoring and plume characterization activities indicate relatively constant or gradually decreasing levels for these contaminants. Uranium is the primary contaminant of concern and remains above the drinking water standard beneath approximately half of the 300 Area. The decrease in concentrations predicted by modeling during the initial remedial investigation has not occurred as expected, so DOE has supported additional investigation of natural processes that lead to reduced concentrations, as well as more detailed groundwater modeling. An update to the focused feasibility study for remedial action alternatives for uranium is also underway. The new information developed by these activities will be used to guide future remedial action decisions.

Groundwater downgradient of the 618-11 burial ground is contaminated by a highconcentration tritium plume, whose origin is believed to be irradiated material in the burial ground. Concentrations at a well adjacent to the burial ground have decreased since maximum values in 2000, but are still the highest observed on the Hanford Site. Continued characterization and modeling are underway to predict the future movement of the narrow plume, which extends $\sim 1$ kilometer to the east of the waste site.

At the 316-4 cribs/618-10 burial ground waste sites, uranium and tributyl phosphate are contaminants of potential concern; both are associated with the 316-4 cribs, which were removed during fall 2004. Current concentrations of uranium in the area are generally below the drinking water standard, although there is some suggestion that excavation activities may have remobilized vadose zone contamination. Tributyl phosphate has been undetected in recent samples. There is no evidence for impacts to groundwater caused by releases from the $618-10$ burial ground. 
316-5 Process Trenches. This liquid waste disposal site was the last in the 300 Area to receive uranium-bearing effluent, with discharges ending in the early 1990s. The trenches have undergone two phases of remedial action (1991 and 1995), which included removal of contaminated soil and operational structures, and backfilling with clean soil. Uranium currently exceeds the drinking water standard in wells downgradient from the waste site, although concentrations appear to be decreasing with time. Cis-1,2, dichloroethene exceeds the standard at only one downgradient well.

\section{0-EM-1 Operable Unit}

This operable unit is in the south part of the Hanford Site. Trichloroethene is the primary contaminant of concern. Contaminants also flow into the area from offsite sources (e.g., nitrate from agriculture and industry).

Selected Remedial Action. The final remedy selected for 1100-EM-1 Operable Unit groundwater is monitored natural attenuation of volatile organic compounds. Average concentrations of trichloroethene have remained below the drinking water standard since FY 2001.

Wells in the city of Richland well field are monitored frequently to detect any changes in Hanford contaminants near these wells. The tritium plume from the 200 East Area has not been detected in these wells. Low levels of tritium, similar to Columbia River water, continued to be detected.

\section{Confined Aquifers}

Although most of Hanford's groundwater contamination is in the unconfined aquifer, DOE monitors wells in deeper aquifers because of the potential for downward migration of contamination and the potential migration of contamination offsite through the basaltconfined aquifer.

The Ringold Formation confined aquifer occurs within fluvial sand and gravel comprising the lowest sedimentary unit of the Ringold Formation. It is confined below by basalt and above by the lower mud unit. Groundwater in this aquifer flows generally west to east in the vicinity of the 200 West Area. In the central portion of the aquifer, flow converges on the 200 East Area from the west, south, and east. Groundwater discharges from the confined aquifer into the overlying unconfined aquifer near the 200 East Area.

While effluent disposal was occurring at the B Pond system, groundwater mounding forced groundwater and any associated contamination a limited distance into the Ringold Formation confined aquifer. Groundwater analyses for FY 2004 at the 200 Area Treated Effluent Disposal Facility continued to demonstrate isolation of the confined aquifer from disposal activities.

Within the upper basalt-confined aquifer system, groundwater occurs within basalt fractures and joints, interflow contacts, and sedimentary interbeds. Groundwater in the upper basalt-confined aquifer generally flows from west to east across the Hanford Site, up through fractures or other pathways in the confining layers, into the unconfined aquifer, and into the Columbia River. Vertical gradients between the basalt-confined aquifer and the unconfined aquifer are upward on most of the Hanford Site. Downward gradients are measured west of the 200 East Area, near B Pond, and north and east of the Columbia River.

Results of sampling basalt-confined groundwater show that tritium was detected in some wells at very low levels, while iodine-129, strontium-90, gamma-emitting isotopes, and uranium isotopes were not detected. Cyanide, nitrate, and technetium-99 were elevated in one well in the north part of the 200 East Area, but contaminant migration during well construction is suspected. Contaminants on the Hanford Site have not migrated through the upper basalt-confined aquifer system to offsite sample locations south and southeast of the Hanford Site.
In some areas, DOE and the regulatory agencies agree that natural processes will clean up groundwater contamination.

This approach is being applied in the 1100-EM-1 Operable Unit, and trichloroethene concentrations continued to be

below the cleanup level.

\section{Cyanide, nitrate, and technetium-99 were elevated in only one basalt- confined well. Contaminant migration during well construction is suspected.}




\section{Well Installation, Maintenance, and Decommissioning}

DOE installs new wells when needed for monitoring or characterization, maintains wells to prevent or repair problems, and decommissions wells that are no longer needed. Ecology, EPA, and DOE worked together to develop a prioritized list of new wells needed to meet requirements of various groundwater monitoring regulations. During calendar year 2004, as approved via Tri-Party Agreement milestone M-24-57D, a total of 25 new wells were installed at the Hanford Site, which included 6 RCRA wells and 19 CERCLA wells. Fifty-one vadose characterization holes were installed in the 200 Areas to support remediation and decommissioned after soil sampling was complete. A total of 278 wells received maintenance, and 98 were decommissioned (filled with grout) because they are no longer needed, were in poor condition, or were in the way of remediation sites. In FY 2004, a total of 108 new aquifer tubes were installed along the shoreline of the 100 and 300 Areas.

\section{Modeling}

Computer simulations of groundwater flow and contaminant movement help predict future conditions and assess the effects of remediation systems. A site-wide numerical model has been developed and is being improved and refined. During FY 2004, the pattern of geologic facies-zones within the Hanford formation and Ringold Formation gravel units of the model has evolved in a continuing effort to improve the calibration of the model. The calibration involves adjusting the facies-zonation configuration, the hydraulic conductivities associated with the facies-zones, and the amounts of recharge to the system in an effort to match historical changes in water-table elevation and the historical movement of tritium. Changes were also made to the configuration of hydrogeologic units in the model based on new well data and reinterpretation of geological contacts at some locations.

DOE applied the site-wide groundwater model to specific waste-site assessments in FY 2004:

- Modeling the movement of tritium disposed to the State-Approved Land Disposal Site north of 200 West Area.

\begin{tabular}{|c|c|c|}
\hline \multicolumn{3}{|c|}{ Wells and Aquifer Tubes Installed in 2004} \\
\hline Site or Purpose & $\begin{array}{l}\text { Number of New Wells } \\
\text { Calendar Year } 2004 \\
\end{array}$ & $\begin{array}{l}\text { Number of New Aquifer Tubes } \\
\text { Fiscal Year } 2004 \\
\end{array}$ \\
\hline 100-BC-5 & 0 & 15 \\
\hline 100-KR-4 & 2 & 18 \\
\hline 100-NR-2 & 3 & 8 \\
\hline 100-HR-3-D & 3 & 14 \\
\hline 100-HR-3-H & 0 & 8 \\
\hline 100-FR-3 & 0 & 12 \\
\hline 200-ZP-1 & 4 & 0 \\
\hline 200-UP-1 & 7 & 0 \\
\hline 300-FF-5 & 0 & 33 \\
\hline Waste Management Area A-AX & 2 & 0 \\
\hline Waste Management Area B-BX-BY & 3 & 0 \\
\hline Waste Management Area U & 1 & 0 \\
\hline Total & 25 & 108 \\
\hline
\end{tabular}


- Site-wide groundwater flow and transport calculations supporting the performance assessment for the Integrated Disposal Facility and the preliminary performance assessment for closure of single-shell tank farms.

- Site-wide modeling of dissolved carbon tetrachloride migration from 200 West Area through the groundwater considering different source conditions and various degrees of sorption and natural degradation.

The System Assessment Capability is an integrated assessment tool that includes several linked computer models designed to simulate the movement of contaminants from waste sites through the vadose zone, groundwater, and Columbia River to receptors. It also incorporates modules that calculate the risks to human health and the environment. During FY 2004, the System Assessment Capability was used to begin the 2004 Composite Analysis. The Composite Analysis is designed to calculate the combined impacts of all radiological waste that will be left on the Hanford Site at the time of site closure.

Local-scale simulations of the movement of dense, non-aqueous liquid (carbon tetrachloride) at the 216-Z-9 trench in the 200 West Area were performed in FY 2004. The purpose of this work was to enhance understanding of carbon tetrachloride in the subsurface beneath the trench to support remediation decisions. The modeling indicated the following results:

- The Cold Creek hydrogeologic unit has a large impact on the modeled migration of carbon tetrachloride through the vadose zone.

- The lateral extent of the modeled dense non-aqueous liquid has not moved laterally outside the footprint of the disposal facility.

- The lateral extent of the modeled vapor-phase plume was much greater than the lateral extent of the dense non-aqueous liquid.

- The vapor-phase plume caused some contamination of underlying groundwater in the model.

\section{Vadose Zone}

Subsurface source characterization, vadose zone monitoring, soil-vapor monitoring, and sediment sampling were conducted in FY 2004.

Remedial investigation reports were issued in FY 2004 that include the results of laboratory analyses of vadose zone samples collected in recent years from boreholes or test pits at various waste sites in the 200 Areas.

During FY 2004, DOE published the results of characterization of two boreholes placed through a 1973 tank leak in the T Tank Farm, 200 West Area. The results of the characterization were compared to characterization results obtained 10 years ago to determine whether contaminants have migrated in the vadose zone. The results were not definitive but suggest that there has been some vertical movement of nitrate and perhaps technetium-99 during the last 10 years. Also during FY 2004, samples from one borehole in the C Tank Farm were studied to characterize contaminants from a potential tank leak in the 1960s.

Borehole geophysics continued to provide vadose zone characterization data in FY 2004. Geophysical logging in new and existing boreholes is used for stratigraphic correlation and to detect and quantify radioactive contaminants. Baseline characterization logging was performed at the 216-A-27 crib, in the B/C crib area, and in the vicinity of the 216-T-6 crib. The $\mathrm{B} / \mathrm{C}$ cribs area is also the subject of a remedial investigation, and the seven existing boreholes were logged to support remedial investigations.

Spectral gamma logs from 769 existing monitoring boreholes in the single-shell tank farms are used to characterize the subsurface contamination with gamma-emitting radionuclides.
Computer models of groundwater help predict movement of contaminants in groundwater and future groundwater conditions. This information is important in planning waste management and cleanup activities at the Hanford Site. 


\section{Geophysical logging in new and existing boreholes is used for stratigraphic correlation and to \\ detect and quantify radioactive} contaminants. By comparing logs run at different times, DOE can detect whether radionuclides

have moved in the

vadose zone.

\section{Casing corrosion} of two wells at Waste Management Area A-AX was apparently caused by chloride in the annular seal of the well and a wet sediment layer in the vadose zone.
During FY 2004, routine monitoring activities were performed in 23 boreholes in BX, BY, C, and S Tank Farms. In general, contaminant plumes identified by baseline characterization appear to be stable over time. In FY 2004, only two boreholes (one each at C and S Tank Farms) exhibited movement to a degree that can be confirmed over a relatively short time interval. However, high-activity zones that constitute the bulk of contaminant inventory in the vadose zone are difficult to monitor over the short term because of the relative error associated with the high-rate logging system.

During waste retrieval operations at single-shell tank farms, monitoring is performed in adjacent boreholes to detect any leaks that may be associated with the retrieval operation. Both gamma activity and neutron moisture measurements are made. During 2004, retrieval operations were continued in tanks C-106 and S-112 and adjacent boreholes were logged.

Composite leachate samples from the Environmental Restoration Disposal Facility contained detectable concentrations of common metals, anions, and mobile radionuclides. Concentrations of chromium, nitrate, gross alpha, technetium-99, and uranium have been generally increasing since 2001. The facility is lined, and there is no evidence of impacts to groundwater.

Soil gas at the Solid Waste Landfill is monitored quarterly to determine concentrations of oxygen, carbon dioxide, methane, and several key volatile organic compounds. No contaminants of concern were discovered above reporting limits during the reporting period.

Soil-vapor extraction is being used to remove carbon tetrachloride from the vadose zone in the 200 West Area. As of October 2004, 78,300 kilograms of carbon tetrachloride have been removed from the vadose zone since extraction operations started in 1991.

Corrosion of the stainless steel casing in two groundwater monitoring wells at Waste Management Area A-AX in the 200 East Area has made the wells unsuitable for use. The corrosion occurred above the water table, and DOE began investigating the cause in FY 2004. Analysis of sidewall core samples yielded a clear relationship between chloride concentration and well casing corrosion. The concentration of chloride in the samples was greatest at the same depth as the degraded well casing. This finding implies that the annular seal material contained the source of chloride in the sidewall core samples. Preliminary results indicate that the advanced well casing corrosion was caused by chloride-facilitated crevice corrosion and stress corrosion cracking. It is possible that the well casing was damaged during installation, which would have accelerated stress corrosion cracking. Additionally, a silt lens likely exacerbated this process by providing a continual source of moisture, which generated localized pore water with high chloride concentrations.

\section{Continued Monitoring}

DOE will continue to monitor groundwater to meet the requirements of AEA, CERCLA, RCRA, and DOE Orders. During ongoing groundwater remediation, the groundwater project will monitor, assess, and report on activities at groundwater operable units. Both the unconfined and upper-confined aquifers are monitored and data are maintained and managed in a centralized database. Monitoring well locations, frequencies, and analytical constituents will continue to be documented each year. Water-level monitoring will continue to be performed to characterize groundwater flow and to determine the impact of Hanford Site operations on the flow system.

As such, groundwater monitoring remains a part of the Hanford Site baseline throughout the cleanup mission and will remain a component of long-term stewardship after remediation is completed.

Details about groundwater monitoring on the Hanford Site can be found online at http://www.hanford.gov/cp/gpp/. 